\title{
A modelling study of tropospheric distributions of the trace gases $\mathrm{CFCl}_{3}$ and $\mathrm{CH}_{3} \mathrm{CCl}_{3}$ in the 1980s
}

\author{
K.-Y. Wang ${ }^{1}$, D. E. Shallcross ${ }^{1,2}$ \\ ${ }^{1}$ Centre for Atmospheric Science, Cambridge University, UK \\ ${ }^{2}$ School of Chemistry, University of Bristol, BS8 1TS, UK \\ Received: 22 November 1999 / Revised: 22 March 2000 / Accepted: 18 April 2000
}

\begin{abstract}
Interhemispheric transport is a key process affecting the accuracy of source quantification for species such as methane by inverse modelling, and is a source of difference among global three-dimensional chemistry transport models (CTMs). Here we use longterm observations of the atmospheric concentration of long-lived species such as $\mathrm{CH}_{3} \mathrm{CCl}_{3}$ and $\mathrm{CFCl}_{3}$ for testing three-dimensional chemistry transport models (CTMs); notably their ability to model the interhemispheric transport, distribution, trend, and variability of trace gases in the troposphere. The very striking contrast between the inhomogeneous source distribution and the nearly homogeneous trend, observed in the global ALE/ GAGE experiments for both $\mathrm{CH}_{3} \mathrm{CCl}_{3}$ and $\mathrm{CFCl}_{3}$ illustrates an efficient interhemispheric transport of atmospherically long-lived chemical species. Analysis of the modelling data at two tropical stations, Barbados $\left(13^{\circ} \mathrm{N}, 59^{\circ} \mathrm{W}\right)$ and Samoa $\left(14^{\circ} \mathrm{S}, 124^{\circ} \mathrm{W}\right)$, show the close relationship between inter-hemispheric transport and cross-equator Hadley circulations. We found that crossequator Hadley circulations play a key role in producing the globally homogeneous observed trends. Chemically, the most rapid interaction between $\mathrm{CH}_{3} \mathrm{CCl}_{3}$ and $\mathrm{OH}$ occurs in the northern summer troposphere; while the most rapid photolysis of $\mathrm{CH}_{3} \mathrm{CCl}_{3}$ and $\mathrm{CFCl}_{3}$, and the chemical reactions between $\mathrm{CFCl}_{3}$ and $\mathrm{O}\left({ }^{1} \mathrm{D}\right)$, take place in the southern summer stratosphere. Therefore, the cross-equator Hadley circulation plays a key role which regulates the southward flux of chemical species. The regulation by the Hadley circulations hence determines the amount of air to be processed by $\mathrm{OH}, \mathrm{O}\left({ }^{1} \mathrm{D}\right)$, and ultraviolet photolysis, in both hemispheres. In summary, the dynamic regulation of the Hadley circulations, and the chemical processing (which crucially depends on the concentration of $\mathrm{OH}, \mathrm{O}\left({ }^{1} \mathrm{D}\right)$, and on the intensity of solar insolation) of the air contribute to the seasonal variability and homogeneous growth rate of observed $\mathrm{CH}_{3} \mathrm{CCl}_{3}$ and $\mathrm{CFCl}_{3}$.
\end{abstract}

Correspondence to: K.-Y. Wang
Key words: Atmospheric composition and structure (middle atmosphere - composition and chemistry; pollution - urban and regional) - Meteorology and atmospheric dynamics (convective processes)

\section{Introduction}

The atmospheric transport of long-lived chemical species by large-scale dynamics is the most important process in the redistribution of trace gases in the atmosphere. The long-range transport of pollutants away from a source area, by the large-scale general circulations provides a key mechanism for non-indigenous pollution events. Hence, it is crucial to study the performance of global three-dimensional (3-D) CTMs with respect to their ability to model transport processes. One way of testing CTM's performance is by studying its ability to model long-lived trace gases, where emission sources are well known and long-term measurements exist, such as chlorofluorocarbons (CFCs).

Trace gases of anthropogenic origin, which contain chlorine and bromine atoms can greatly perturb stratospheric ozone concentrations (e.g. see Solomon, 1999). Most of these man-made chemical species are longlived. For example, the inferred lifetime for $\mathrm{CFCl}_{3}$ is about 43-50 years and 4.1-5.4 years for $\mathrm{CH}_{3} \mathrm{CCl}_{3}$ (Kaye et al., 1994). The longevity of these halogenated species greatly enhances the probability and magnitude of their stratospheric influx. Once they reach the middle atmosphere, they will be destroyed by ultraviolet photolysis and by chemical reaction with $\mathrm{O}\left({ }^{1} \mathrm{D}\right)$, releasing active chlorine and bromine atoms into the stratosphere. The subsequent threat to ozone can be examined by detailed examination of catalytic chemistry involving chlorine or bromine-containing compounds (e.g. Wayne, 1993).

The ALE/GAGE experiment, which began in 1978, provides a continuous long-term record of surface observations of the concentrations of the atmospheri- 
cally long-lived chemical species (Prinn et al., 1983, 1992; Cunnold et al., 1994). The measurements include two gases which have both anthropogenic and biogenic sources $\left(\mathrm{CH}_{4}\right.$ and $\left.\mathrm{N}_{2} \mathrm{O}\right)$ and five gases of anthropogenic origin $\left(\mathrm{CFCl}_{3}, \mathrm{CF}_{2} \mathrm{Cl}_{2}, \mathrm{CF}_{2} \mathrm{ClCFCl}_{2}, \mathrm{CH}_{3} \mathrm{CCl}_{3}\right.$, and $\mathrm{CCl}_{4}$ ). The use of this long-term surface observational record of $\mathrm{CH}_{3} \mathrm{CCl}_{3}$ and $\mathrm{CFCl}_{3}$ from global ALE/GAGE network stations, combined with their anthropogenic emissions, which are reasonably well known and the well-established chemistry (CFCs, HFCs, and HCFCs) by laboratory studies, provide a sound platform for a modelling study. The purpose of this modelling study can be summarized by the following: to derive the threedimensional distributions of $\mathrm{CFCl}_{3}$ and $\mathrm{CH}_{3} \mathrm{CCl}_{3}$; to study the atmospheric transport processes once these species have been released into the air; and to investigate their trend and variability.

If we consider the following two facts: first there is a near globally homogeneous trend in the concentration of $\mathrm{CH}_{3} \mathrm{CCl}_{3}$ and $\mathrm{CFCl}_{3}$ observed during the ALE/GAGE experiments; second, nearly $95 \%$ of the reported sources of those two species are in the Northern Hemisphere with maxima centred around mid-latitudes. Then, the very striking contrast between inhomogeneous source distribution and nearly homogeneous observed trend in the global ALE/GAGE stations, strongly suggests an efficient inter-hemispheric transport of anthropogenic chemical species. This indication of efficient interhemispheric transport also emerged from another modelling study of ${ }^{85} \mathrm{Kr}$. (Müller and Brasseur, 1995).

The variability of the observed surface concentration of chemical species by atmospheric transport processes has been pointed out by other studies (Prather et al., 1987; Prinn et al., 1992; Hartley et al., 1993). The role of vertical transport by cloud convection on the observed seasonal cycle of the surface concentration has been noted by the modelling study of $\mathrm{CFCl}_{3}$ and $\mathrm{CF}_{2} \mathrm{Cl}_{2}$ over the continental areas (Prather et al., 1987). Cloud convection also plays an important role with respect to interhemispheric transport of trace gases (Gilliland and Hartley, 1998). The variation of the northern Atlantic storm tracks has a direct influence on the observations at Mace Head in Ireland (Hartley et al., 1993), and the ENSO event could have a strong influence of the influx of Northern Hemispheric air in the boreal winter (Prinn et al., 1992). Hence a close relationship between specific atmospheric transport process and the observed variability of surface concentration has long been inferred. The focus of this modelling study is to specifically investigate the observed variability of surface concentration by a variety of atmospheric transport processes. We will concentrate our analysis on the process of interhemispheric transport, because it is the key factor for the variability and globally homogeneous trends of concentration of chemical species.

\section{Model description}

The 3-D CTM (Stockwell and Chipperfield, 1999) used in this study includes parametrizations for transport by subgrid scale processes and chemical reactions which lead to the destruction of $\mathrm{CH}_{3} \mathrm{CCl}_{3}$ and $\mathrm{CFCl}_{3}$. The parametrizations of sub-grid scale transport in the model include cumulus convection, atmospheric boundary layer processes and sub-grid scale diffusive transport.

The cumulus parametrization method (Tiedtke, 1989) used in this study is a mass flux scheme (Stockwell and Chipperfield, 1996). The Tiedtke (1989) cumulus scheme considers the cloud model with the following components: in-cloud updraught, downdraught, large-scale subsidence induced by cumulus motion, entrainment and detrainment processes into in-cloud updraught and downdraught air. The scheme therefore considers only the cumulus scale updraughts, as well as downdraughts, but neglects mesoscale circulations. The closure of the scheme is based on the observational evidence that typical cloud ensembles prevail under certain synoptic conditions. For example, the pre-existence of large-scale low level convergence could moisten and destabilize the environment at low levels, so that small-scale thermals can easily reach the level of free convection and produce deep cumulus convection (Holton, 1992). The key point for the whole mechanism to work is that the low-level large-scale convergence produces a convergence of moisture, which by increasing the equivalent potential temperature in the boundary layer makes the environment more favorable for the development of the cumulus convection.

The transport within the atmospheric boundary layer (ABL) has been parametrized by the local- $K$ scheme (Louis, 1979; Heimann, 1994; Holtslag and Boville, 1993) plus a simplified boundary layer height calculation to enhance vertical transport of chemical species by large eddy transport in the atmospheric boundary layer. The assumption of the calculation of boundary layer height used in this study is based on the observations of the diurnal variation of boundary layer height (Driedonks, 1982; Deardorff, 1972). The lowest boundary layer height is assumed to be $1 \mathrm{~km}$, and a sine wave variation with amplitude of $2 \mathrm{~km}$ is added according to the time of the day. The maximum boundary layer height is therefore $3 \mathrm{~km}$ at noon with a minimum of $1 \mathrm{~km}$ at midnight. This amplitude is comparable with that calculated by the nonlocal scheme (Holtslag and Boville, 1993) where the diurnal amplitude ranges from $0.5 \mathrm{~km}$ to $4 \mathrm{~km}$ according to different geophysical locations. The purpose of the boundary layer height is to give an estimated vertical scale of dry convection, which is then used to provide an additional mechanism for vertical transport of species within the ABL. The effect of horizontal diffusive mixing induced by the cumulus convection has been applied to the cloudy model column to account for the enhanced sub-grid scale horizontal entraintment and detrainment of air into the cloud (Stockwell and Chipperfield, 1999), which it is not possible to properly represent in the low-resolution model, and which was shown to affect the interhemispheric tracer transport over the intertropical convergence ozone (Prather et al., 1987).

A simple gas phase chemistry scheme, includes the reaction between $\mathrm{CH}_{3} \mathrm{CCl}_{3}$ and $\mathrm{OH}$, and $\mathrm{CFCl}_{3}$ with 
$\mathrm{O}\left({ }^{1} \mathrm{D}\right)$ is shown in Table 1. This chemical scheme and photolysis of the two trace species in the stratosphere are the major sinks for both species. Prescribed two dimensional fields of photolysis rates, $\mathrm{OH}$, and $\mathrm{O}\left({ }^{1} \mathrm{D}\right)$, which take into account the seasonal variation of photolysis rates, $\mathrm{OH}$, and $\mathrm{O}\left({ }^{1} \mathrm{D}\right)$, have been used in the chemical calculation. These fields were obtained from the Cambridge 2D model which includes a detailed description of tropospheric chemistry (Law and Pyle, 1993) and are updated every 10 days.

The emissions data from 1981 to 1990 of Midgley (1992) have been used here to construct the surface sources of $\mathrm{CH}_{3} \mathrm{CCl}_{3}$ and $\mathrm{CFCl}_{3}$ from 1979 to 1988 . The reported emissions for $\mathrm{CFCl}_{3}$ represents around $85 \%$ of the actual emission into atmosphere, therefore the emissions used in the model for $\mathrm{CFCl}_{3}$ have been scaled by a factor $1 / 0.85$ of the value from Midgley (1992). The actual emission used is summarized in the first and second column of Table 2. For comparison, we also list the value estimated from Kaye et al. (1994). The geographical distribution of the emissions is similar to the one used by Hartley and Prinn (1993).

\section{Experiments}

An initialization procedure similar to Golombek and Prinn (1986) has been used in this study, the difference being is that the vertical profiles from the $2 \mathrm{D}$ model have been used in combination with the observed ALE/ GAGE data. The observed value of $\mathrm{CH}_{3} \mathrm{CCl}_{3}$ and

Table 1. Chemical reactions considered in the model

\begin{tabular}{|c|c|}
\hline $\begin{array}{l}(\mathrm{R} 1) \\
\text { (R2) } \\
\text { (R3) } \\
\text { (R4) }\end{array}$ & $\begin{array}{l}\mathrm{CH}_{3} \mathrm{CCl}_{3}+\mathrm{OH} \longrightarrow \mathrm{CH}_{2} \mathrm{CCl}_{3}+\mathrm{H}_{2} \mathrm{O} \\
\mathrm{CH}_{3} \mathrm{CCl}_{3}+\mathrm{h} v \longrightarrow \mathrm{CH}_{3} \mathrm{CCl}_{2}+\mathrm{Cl} \\
\mathrm{CFCl}_{3}+\mathrm{h} v \longrightarrow \mathrm{CFCl}_{2}+\mathrm{Cl} \\
\mathrm{CFCl}_{3}+\mathrm{O}\left({ }^{1} \mathrm{D}\right) \longrightarrow \mathrm{CFCl}_{2}+\mathrm{ClO}\end{array}$ \\
\hline $\begin{array}{l}\text { Where } \\
\text { and }\end{array}$ & $\begin{array}{l}\mathrm{k}_{\left[\mathrm{CH}_{3} \mathrm{CCl}_{3}\right][\mathrm{OH}]}=1.75 \times 10^{-12} \exp (-1550 / \mathrm{T})^{\mathrm{a}}\left(\mathrm{cm}^{3} \mathrm{sec}^{-1}\right) \\
\mathrm{k}_{\left[\mathrm{CFCl}_{3}\right]\left[\mathrm{O}\left({ }^{1} \mathrm{D}\right)\right]}=2.3 \times 10^{-10 \mathrm{~b}}\left(\mathrm{~cm}^{3} \mathrm{sec}^{-1}\right)\end{array}$ \\
\hline
\end{tabular}

Table 2. Global annual emissions, $10^{8} \mathrm{~kg}$

\begin{tabular}{lcccc}
\hline Year & $\mathrm{CH}_{3} \mathrm{CCl}_{3}{ }^{\mathrm{a}}$ & $\mathrm{CFCl}_{3}{ }^{\mathrm{a}}$ & $\mathrm{CH}_{3} \mathrm{CCl}_{3}{ }^{\mathrm{b}}$ & $\mathrm{CFCl}_{3}{ }^{\mathrm{b}}$ \\
\hline 1979 & 5.480 & 3.344 & 5.11 & 2.759 \\
1980 & 5.120 & 2.818 & 5.39 & 2.645 \\
1981 & 5.400 & 2.974 & 5.48 & 2.637 \\
1982 & 6.000 & 3.189 & 5.21 & 2.571 \\
1983 & 5.870 & 3.304 & 5.34 & 2.734 \\
1984 & 6.080 & 3.472 & 5.84 & 2.951 \\
1985 & 6.270 & 3.654 & 5.91 & 3.083 \\
1986 & 6.790 & 3.700 & 6.02 & 3.268 \\
1987 & 6.940 & 3.120 & 6.22 & 3.458 \\
1988 & 7.260 & 2.542 & 6.66 & 3.536 \\
Total & 61.210 & 32.117 & 57.180 & 29.642 \\
\hline
\end{tabular}

a Midgley (1992)

${ }^{\mathrm{b}}$ Kaye et al. (1994)
$\mathrm{CFCl}_{3}$ in ALE/GAGE stations is first interpolated, using the cubic spline method, to the model Gaussian latitude and the 2D fields are then normalized in accordance with the interpolated data in the lowest model layer. The normalization factor is then used to modify the value vertically. The advantage of this initialization method is that it maintains the original $2 \mathrm{D}$ vertical profile and also assimilates the observed data.

There is no exchange of species flux across the lower and upper model boundaries. The emission is treated as being added uniformly into the lowest model layer. The assumption is that the lowest model layer, about $70 \mathrm{~m}$ deep, is very turbulent, and with a time step of $3 \mathrm{~h}$, it is expected that there will be quick mixing after the release of species from the surface through the lowest model layer. The dynamic fields, which are relative vorticity, divergence, temperature, specific humidity and surface pressure from UGCM's AMIP experiment have been used as an input to the CTM (Gates, 1992; Slingo et al., 1994). The 10 years AMIP archive, which is at T42 resolution (approximately $2.5^{\circ}$ by $2.5^{\circ}$ ), is first processed to $\mathrm{T} 10$ resolution $\left(11.25^{\circ}\right.$ by $\left.11.25^{\circ}\right)$ before being incorporated into the CTM. A complete set of 10 years of dynamical fields at T10 resolution is then used in the subsequent integration, which saves both CPU time and memory space. The time step for integration is $3 \mathrm{~h}$. The model resolution is 32 longitude grids, 16 Gaussian latitude grids, and 19 layers in the vertical. The input UGCM data is the one generated from AMIP with an annual SST (sea surface temperature) change during the 10 year integration.

\section{Results and discussions}

\subsection{Model results}

One of the most striking features from the observations is the near homogeneous trend of the concentrations of $\mathrm{CH}_{3} \mathrm{CCl}_{3}$ and $\mathrm{CFCl}_{3}$ shown in global ALE/GAGE network stations. (See Figs. 1, 2 and the second and fourth column of Table 3). The near homogeneous global trend of chemical species indicates efficient interhemispheric transport in the tropics. Further evidence which supports an efficient inter-hemispheric transport is also found in the modelling study of ${ }^{85} \mathrm{Kr}$ (see Fig. 4 of Müller and Brasseur, 1995). Approximately $95 \%$ of $\mathrm{CFCl}_{3}$ and $\mathrm{CH}_{3} \mathrm{CCl}_{3}$ emissions come from the Northern Hemisphere industrialized countries. The source of ${ }^{85} \mathrm{Kr}$ comes exclusively from pressurized water nuclear reactors in the Northern Hemisphere.

Table 3 summarizes the results from model and observations. At the end of 10 years of integrations, for $\mathrm{CFCl}_{3}$, the difference between the model and observed level is $32.39 \mathrm{pptv}$ in Ireland (Mace Head) and $25.75 \mathrm{pptv}$ in Tasmania. The meridional gradient between Ireland and Tasmania is about $0.36 \mathrm{pptv}$ degree $^{-1}$ from the model and 0.28 pptv degree $^{-1}$ from observations. For $\mathrm{CH}_{3} \mathrm{CCl}_{3}$, the difference between model and observation is $64.95 \mathrm{pptv}$ in Ireland and 

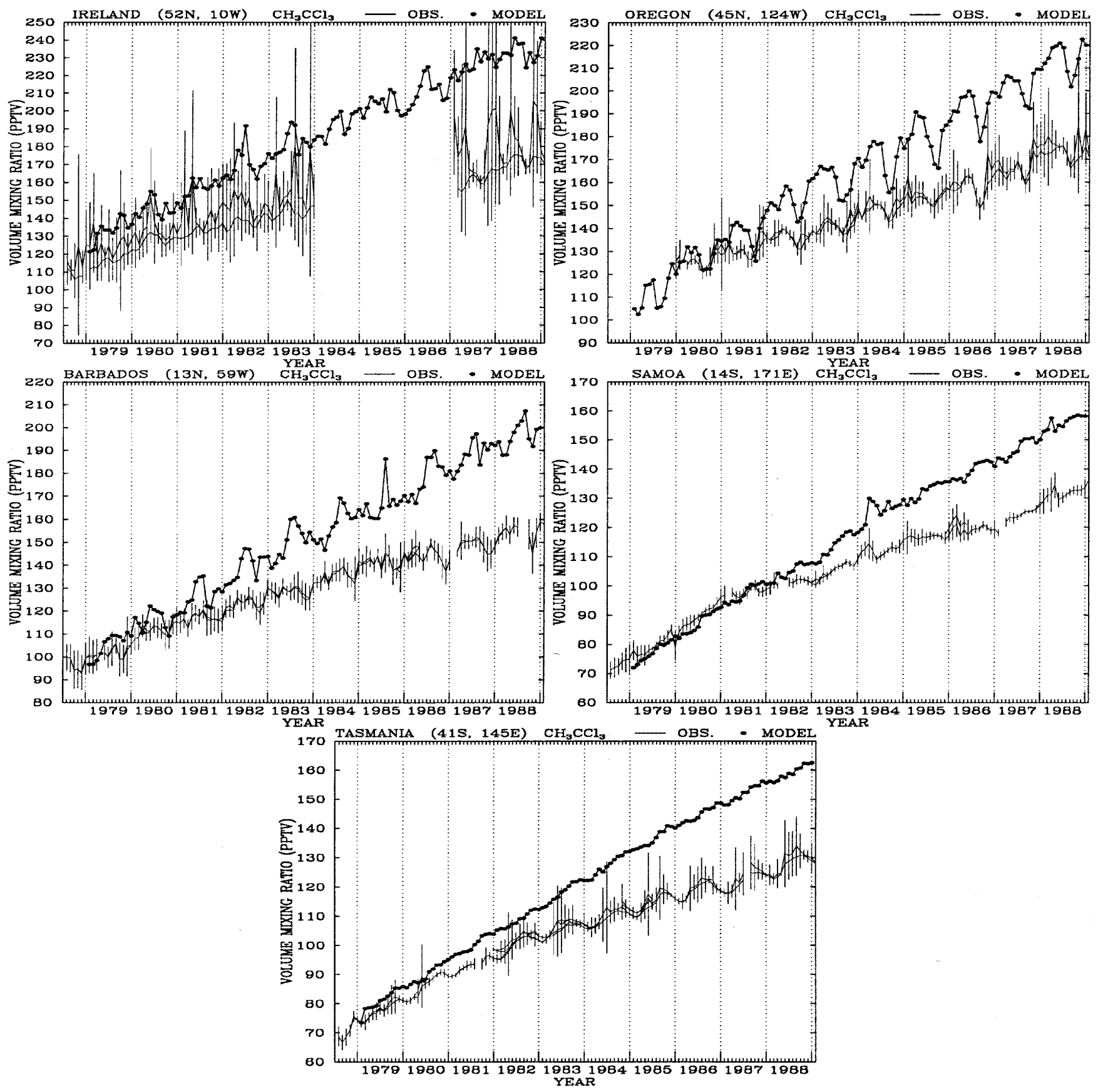

Fig. 1. Observed and modelled (dots) monthly mean concentration of $\mathrm{CH}_{3} \mathrm{CCl}_{3}$ in $\mathrm{ALE} / \mathrm{GAGE}$ stations

$33.26 \mathrm{pptv}$ in the Tasmania. The meridional gradient between Ireland and Tasmania is $0.71 \mathrm{pptv}$ degree $^{-1}$ from the model compared with $0.47 \mathrm{pptv}$ degree $^{-1}$ from observations. The modelled meridional gradient between Ireland and Tasmania for $\mathrm{CH}_{3} \mathrm{CCl}_{3}(0.71 \mathrm{pptv}$ degree $\left.^{-1}\right)$ is greater than $\mathrm{CFCl}_{3}\left(0.36\right.$ pptv degree $\left.{ }^{-1}\right)$; while this difference is less pronounced in the observations where the meridional gradient is $0.47 \mathrm{pptv}$ degree $^{-1}$ for $\mathrm{CH}_{3} \mathrm{CCl}_{3}$ and 0.28 pptv degree ${ }^{-1}$ for $\mathrm{CFCl}_{3}$.

Figures 1 and 2 show the results from the 10-year integration for both chemical species and the comparison with measurements. The model agrees well with the measurements in the first 3 years. After that, the gap between the model and measurement becomes wider (a topic we will return to later). It is clear that there is a seasonal cycle for $\mathrm{CH}_{3} \mathrm{CCl}_{3}$, which reflects the strong seasonality of the $\mathrm{OH}$ field. The model captures this seasonality well, however, the model overestimates the magnitude of the seasonal variability observed in Oregon and underestimates it in Tasmania.

Since $\mathrm{CFCl}_{3}$ is chemically inactive in the troposphere, its time series shown in Fig. 2 reflects the major contributions due to atmospheric transport processes and year-to-year surface emission strength. There are no pronounced seasonal cycles observed for this species, 

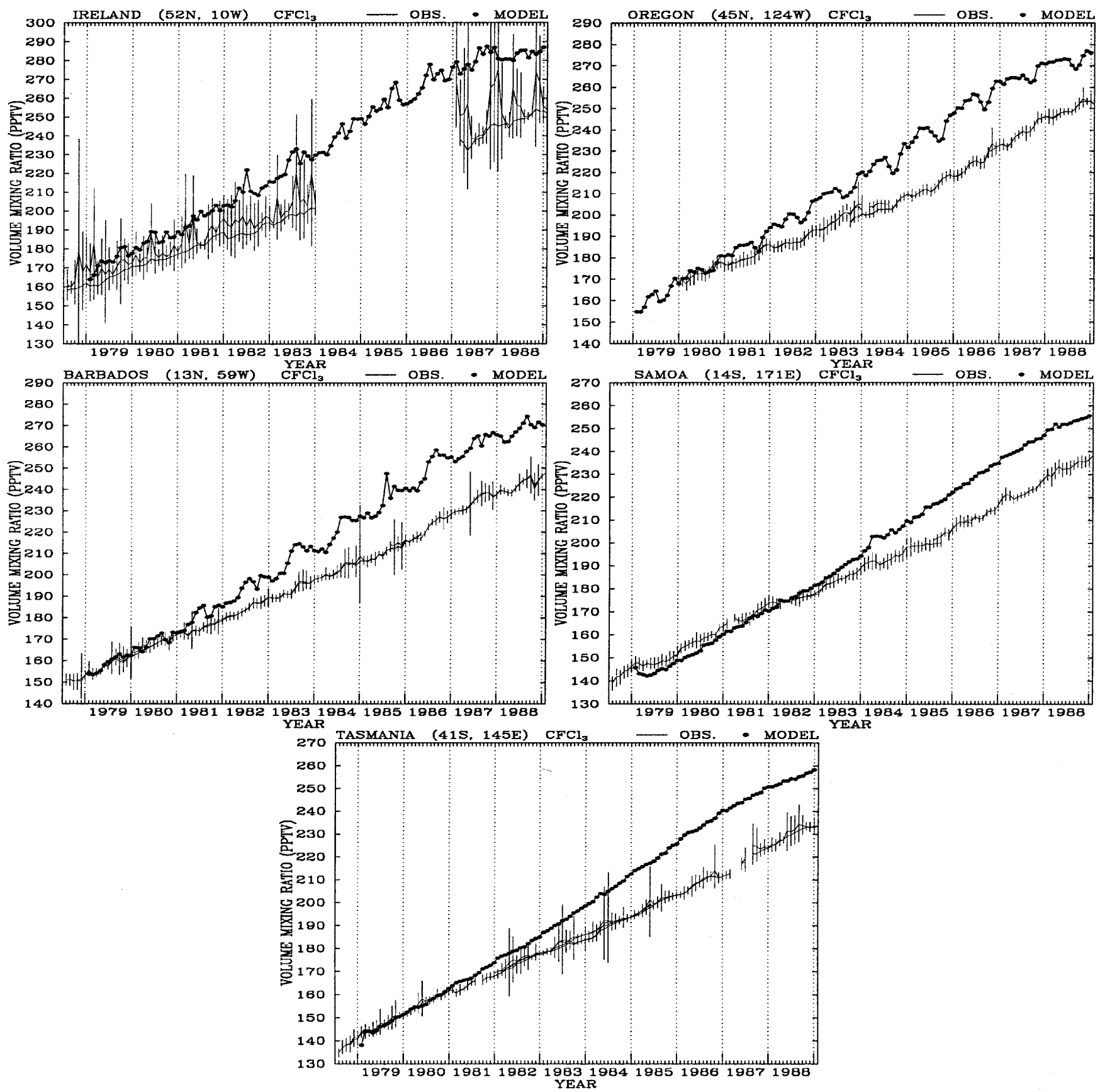

Fig. 2. Observed and modelled (dots) monthly mean concentration of $\mathrm{CFCl}_{3}$ in $\mathrm{ALE} / \mathrm{GAGE}$ stations

Table 3. Observed and modelled trend

\begin{tabular}{lllll}
\hline $\begin{array}{l}\text { Pptv } \\
\text { Station }\end{array}$ & $\begin{array}{l}\mathrm{CH}_{3} \mathrm{CCl}_{3} \\
\text { Model-observations }\end{array}$ & $\begin{array}{l}\mathrm{CH}_{3} \mathrm{CCl}_{3} \\
\text { Observations trend }\end{array}$ & $\begin{array}{l}\mathrm{CFCl}_{3} \\
\text { Model-observations }\end{array}$ & $\begin{array}{l}\mathrm{CFCl}_{3} \\
\text { Observations trend }\end{array}$ \\
\hline Ireland & 64.95 & 58.15 & 32.39 & 90.48 \\
Oregon & 40.02 & $60.22^{\mathrm{a}}$ & 22.58 & $92.72^{\mathrm{a}}$ \\
Barbados & 41.12 & 58.25 & 24.08 & 90.72 \\
Samoa & 24.67 & 55.50 & 19.20 & 88.55 \\
Tasmania & 33.26 & 56.05 & 25.75 & 89.35 \\
\hline
\end{tabular}

The first and third columns represent the difference (surface concentrations, pptv) between modelled and observation for December 1988. The second and fourth columns represent the observed difference of surface concentrations between December 1988 and January 1979

${ }^{a}$ Value was calculated from data which started in December 1979 
however, a noticeable seasonable cycle was observed in Oregon, although relatively weak compared with $\mathrm{CH}_{3} \mathrm{CCl}_{3}$. Hence, this confirms that a possible cause for the pronounced seasonal cycle observed for $\mathrm{CH}_{3} \mathrm{CCl}_{3}$ is due to the active chemical sinks in the troposphere. The pronounced seasonal cycle is clearly seen at sites such as Oregon, Barbados, and Tasmania for $\mathrm{CH}_{3} \mathrm{CCl}_{3}$. While no clear seasonal cycle is seen for observed $\mathrm{CFCl}_{3}$, the model shows a distinctive seasonal cycle for this species at Oregon and Barbodos. This more pronounced $\mathrm{CFCl}_{3}$ seasonal cycle in the model than the measurements indicates an additional transport effect can also be responsible for the modelled $\mathrm{CH}_{3} \mathrm{CCl}_{3}$ seasonal cycle at these sites. Hence, in addition to the modelled $\mathrm{CH}_{3} \mathrm{CCl}_{3}$ seasonal variability driven by the $\mathrm{OH}$ seasonal variability, the transport process also contributes to the higher magnitude of seasonality than the measurements at these sites.

The 10-year average concentration for the lowest model layer is shown in Fig. 3 for both $\mathrm{CH}_{3} \mathrm{CCl}_{3}$ and $\mathrm{CFCl}_{3}$. The bold numbers within each figure show ALE/ GAGE observed concentrations. The maintenance and seasonal movement of inter-tropical high meridional gradient zones of chemical species is clearly seen in the figure. The statistics clearly illustrate the correlation between high concentration areas and high emission sources, which are centred around North America, Europe and Japan. Higher surface concentrations in winter than in summer indicates less active vertical transport of surface emissions into the free troposphere during the winter months.
The seasonal change of surface concentration also reveals a pattern of temporal and spatial variability of chemical species arising from a combination of atmospheric processes. The tongue of lower concentration from low latitude into high latitude and the intrusion of high concentration from high latitude into low latitude in both the eastern North Pacific Ocean and Atlantic Ocean shows the prevailing influence of the subtropical high in that area during the northern summer season. These are two of three major intrusions of high concentrations of these species from high latitude into low latitude. The other major intrusion of high concentrations from high latitude into low latitude occurs in eastern Asia during the winter season, as seen from Fig. 3. The intense continental Mongolian or Siberian High developed during winter usually produces the well-known northeast monsoon season, a prevailing strong wind which produces the southward intrusion pattern.

The zonally averaged concentration at each model layer for $\mathrm{CH}_{3} \mathrm{CCl}_{3}$ and $\mathrm{CFCl}_{3}$ for the summer and winter season is shown in Fig. 4. The distinct contrast between summer and winter clearly shows the seasonal variation of the Hadley cell circulation in the tropical region. The long-lived species are therefore suitable candidates for seeing the underlying dynamics, a useful quality which also belongs to some dynamic tracers such as isentropic potential vorticity under adiabatic isentropic motions (Hoskins et al., 1985). The significant difference in the vertical gradient of concentration shows the approximate position of the tropopause.
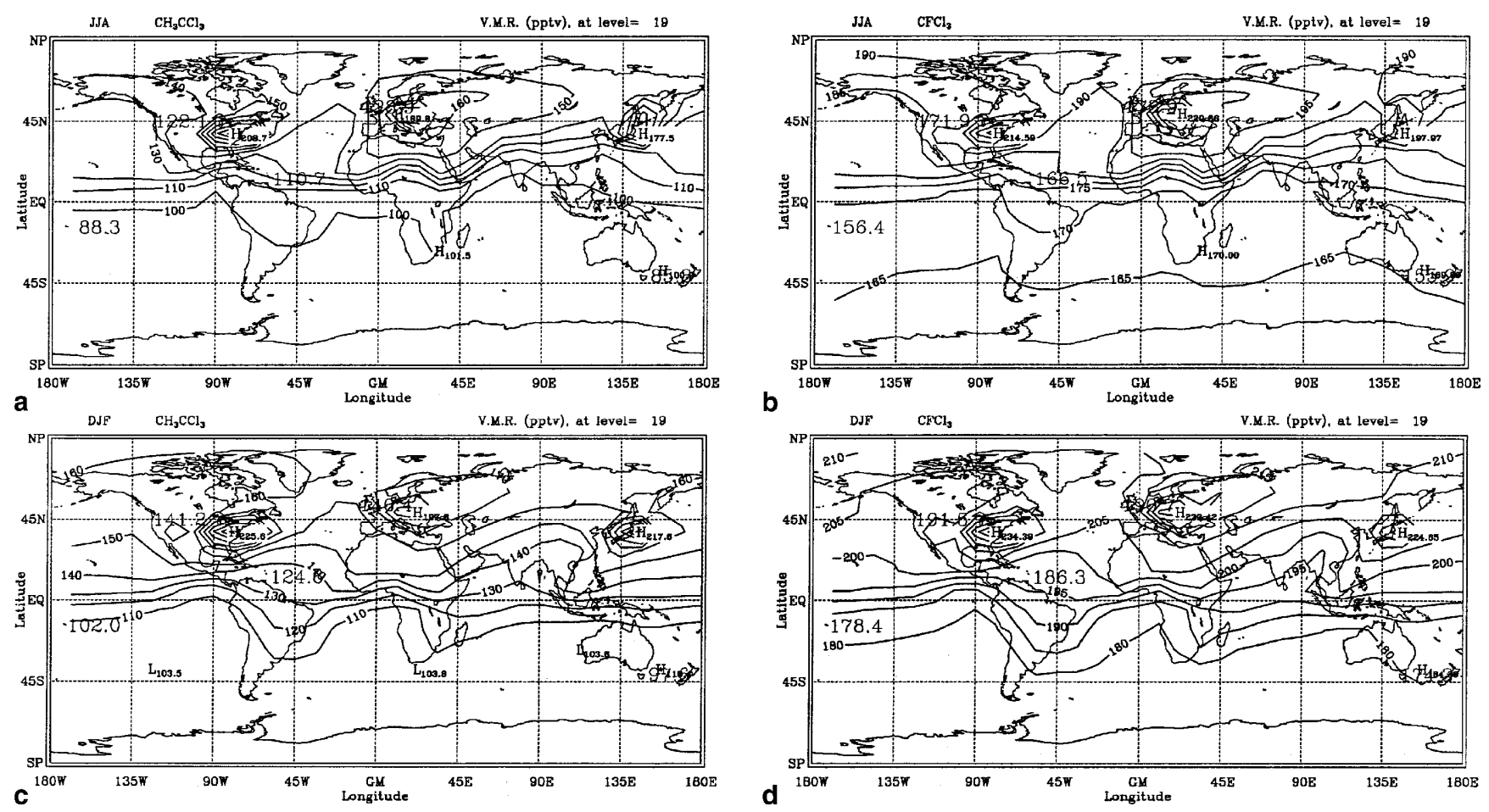

Fig. 3a-d. A 10-year average of modelled surface concentration (pptv) a, $\mathbf{c}$ of $\mathrm{CH}_{3} \mathrm{CCl}_{3}$ and $\mathbf{b}, \mathbf{d} \mathrm{CFCl}_{3}$ for both summer (a, b) and winter (c, d) seasons. The bold numbers within each plot are the 10-year averaged values from ALE/GAGE experiments 

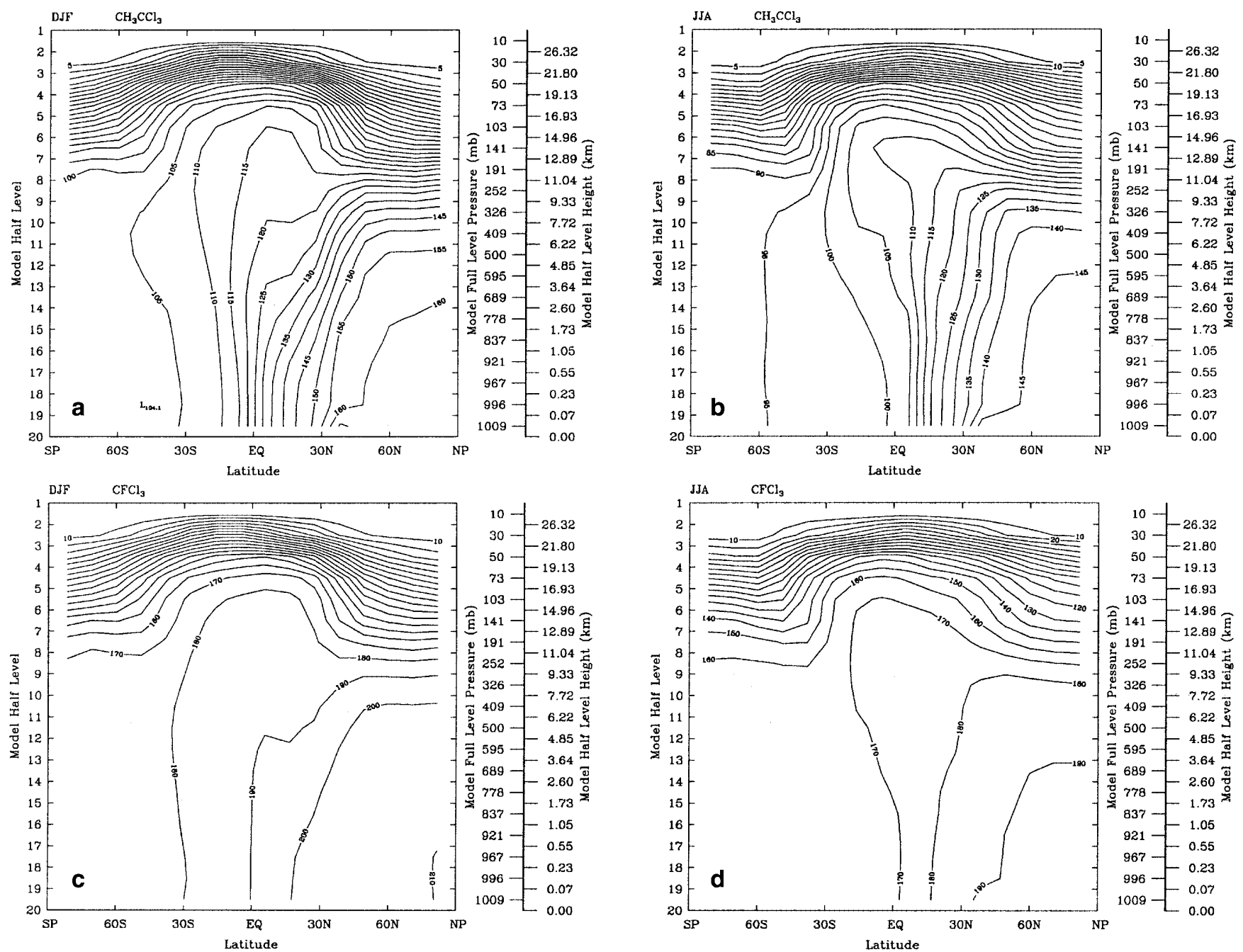

Fig. 4a-d. Zonal averaged meridional-height cross section of 10-year averaged concentration (pptv) of $\mathrm{CH}_{3} \mathrm{CCl}_{3}(\mathbf{a}, \mathbf{b})$ and $\mathrm{CFCl}_{3}(\mathbf{c}, \mathbf{d})$ for the winter (a, c) and summer (b, d) seasons

The highly stratified structure in the vertical direction of concentration in the stratosphere is distinct from the vertically well mixed structure in the troposphere, which has a stronger meridional gradient. These two distinct types of structure of concentration demonstrate the different mixing processes within each region.

The wind field of the lowest model layer is shown in Fig. 5 for the winter and summer season respectively. The circulation pattern which shows the strength and position of the subtropical high in the Eastern North Pacific Ocean and Atlantic Ocean is clearly seen. These are two major persistent circulation systems which have a direct impact on the transport of species from their surrounding major emission sources. The wind pattern which shows the southwest Asian monsoon is also clearly seen in the area centred around $90^{\circ} \mathrm{E}$. The wind pattern in this area completely changes from southwest to northeast in the winter season, which is the northeast monsoon season. The annual reversal of the wind direction results in this area being one where active inter-hemispheric air exchange take place.

\subsection{Budget analysis}

In previous discussions we have shown that the nearly homogeneous growth of surface concentrations (both modelled and measured) at a network of global monitoring locations with respect to the very inhomogeneous surface source distribution between Northern and Southern Hemispheres indicates an effective interhemispheric transport in redistributing species. Interhemispheric transport is a key process affecting the accuracy of source quantification for species such as methane by inverse modelling (Houweling et al., 1999), and is a source of difference among global threedimensional chemistry transport models (CTMs) (Denning et al., 1999). Vay et al. (1999) showed that the $\mathrm{CO}_{2}$ distribution in the Southern Hemisphere appeared to be largely determined by the interhemispheric transport as air masses with depleted $\mathrm{CO}_{2}$ levels characteristic of the Northern Hemisphere were frequently observed south of the Intertropical Convergence Zone (ITCZ). Quay et al. (1999) observed that a high $\delta^{13} \mathrm{C}$ value in the Southern Hemisphere compared with the Northern Hemisphere 

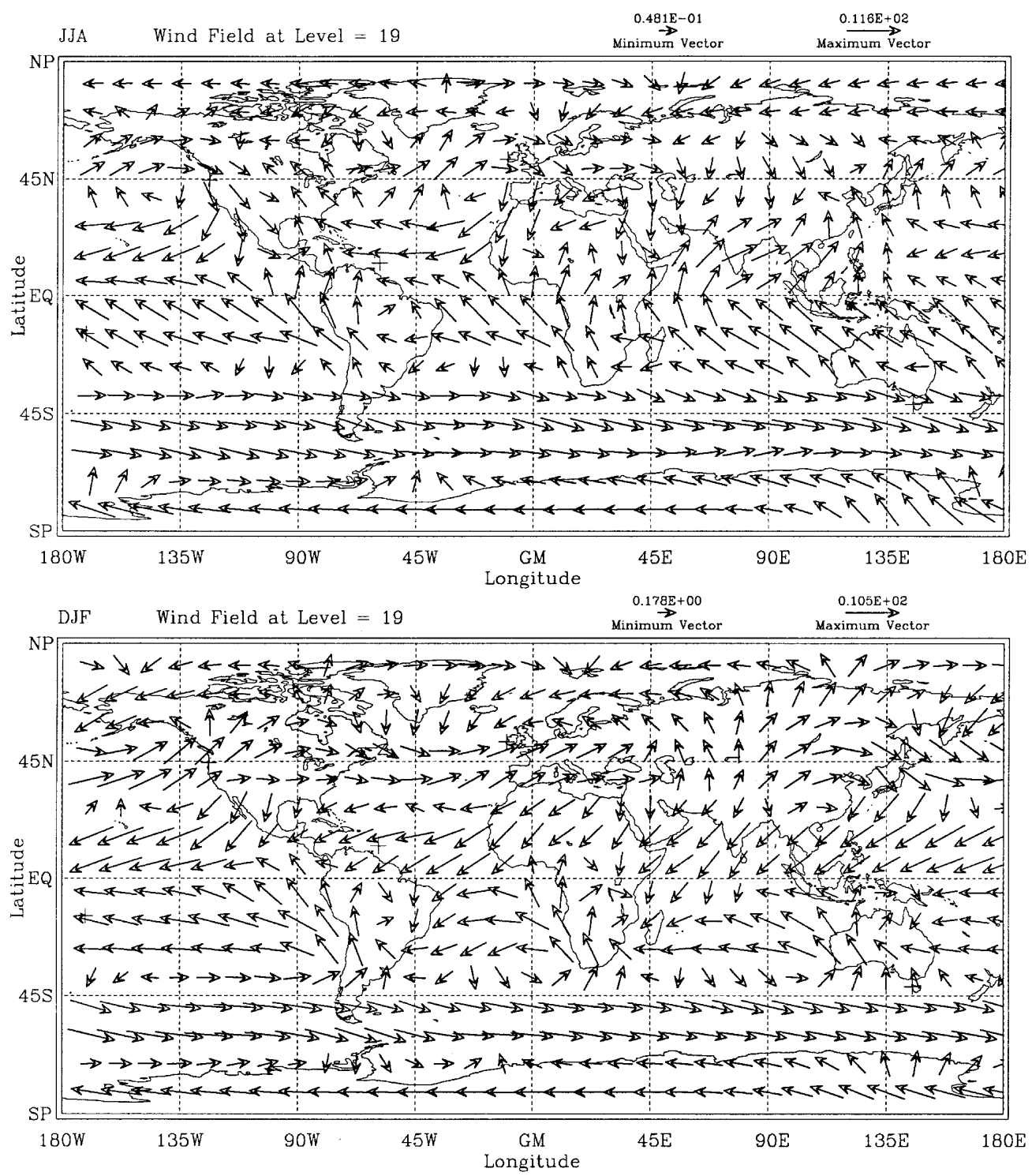

Fig. 5a, b. A 10-year average of surface wind fields in the lowest model layer for a the summer and $\mathbf{b}$ winter seasons

was a result of interhemispheric transport. Hence the study of the role of the interhemispheric transport is very important in characterizing both global pollutant redistribution and source inversion (see also Rhoads et al., 1997). In this section, based on ten years of modelled budget, we examine those key interhemispheric transport processes, namely large-scale advection and cloud convection.

If we consider only the effects of advection, cloud convection, and chemistry, the continuity equation for a chemical species $i$ can be written as

$$
\begin{aligned}
\frac{\partial n_{i}}{\partial t}= & \left(\frac{\partial n_{i}}{\partial t}\right)_{\text {chemistry }}+\left(\frac{\partial n_{i}}{\partial t}\right)_{\text {convection }} \\
& -\frac{\partial}{\partial x}\left(n_{i} u\right)-\frac{\partial}{\partial y}\left(n_{i} v\right)-\frac{\partial}{\partial z}\left(n_{i} w\right)
\end{aligned}
$$

Here $n_{i}$ is the number density of species $i$, and the five terms on the right-hand side of Eq. (1) are the effects of chemistry, cloud convection, horizontal advection by zonal wind $u$ in the east-west direction $x$, meridional advection by meridional wind $v$ in the north-south direction $y$, and vertical advection by vertical wind $w$ in the vertical direction $z$. In the following budget calculation, the effect of transport due to large-scale advection (primarily horizontal and meridional advection), chemistry, and cloud convection during each time step $\triangle t$ were calculated on each box and stored throughout the 10 years of integration. These 3 -D budget terms were then weighted by the volume of the air mass in each model box to give a change of mass $(\mathrm{kg})$ for each species $i$ at each corresponding location (altitude, latitude, and longitude) of the model grid box.

Figure 6 shows a budget analysis for $\mathrm{CH}_{3} \mathrm{CCl}_{3}$ and $\mathrm{CFCl}_{3}$ due to large-scale transport at the northern tropical site of Barbados. The seasonal variability of transport is clearly seen in this tropical station. The major mean meridional circulation in the tropics is dominated by the Hadley circulation (Hastenrath, 1985; Palmen and Newton, 1969). In the northern summer, the Hadley circulation in the north is weak and the accompanying mass circulation is about 

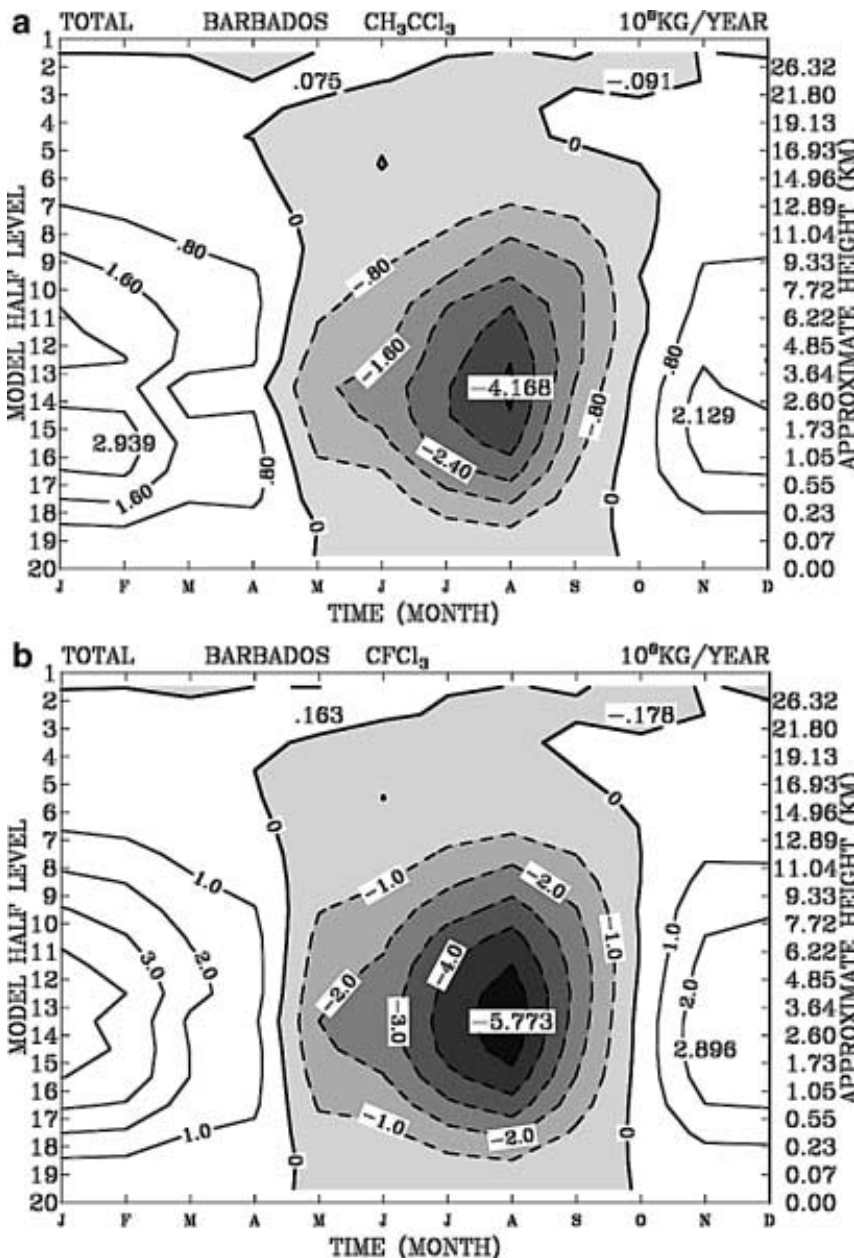

Fig. 6a, b. Height-time plots of 10-year average of a $\mathrm{CH}_{3} \mathrm{CCl}_{3}$ and (b) $\mathrm{CFCl}_{3}$ budget (in units of $10^{6} \times \mathrm{kg}_{\text {year }}{ }^{-1}$ layer ${ }^{-1}$ ) at Barbados site due to large-scale transports. The positive contours indicate that the large-scale transport contributes to the increase in both species at this site; while negative contours (shaded areas) represent the decrease in species at the same site

$8 \times 10^{17} \mathrm{~kg} \mathrm{yr}^{-1}$; while the Southern Hemispheric Hadley circulation with its extension across the equator from the south is most vigorously developed and the accompanying mass circulation is about $6 \times 10^{18} \mathrm{~kg} \mathrm{yr}^{-1}$ (Hastenrath, 1985). In the northern winter, the Hadley circulation in the south is weak and the accompanying mass circulation is about $9 \times 10^{17} \mathrm{~kg} \mathrm{yr}^{-1}$; while the Northern Hemispheric Hadley circulation with its extension across the equator from the north is most vigorously developed and the accompanying mass circulation is about $7 \times 10^{18} \mathrm{~kg} \mathrm{yr}^{-1}$ (Palmen and Newton, 1969).

The domain of influence by the Southern Hemispheric Hadley circulation in the northern summer is between $15^{\circ} \mathrm{N}$ and $25^{\circ} \mathrm{S}$; while the domain for the Northern Hemispheric Hadley circulation in the northern winter is between $28^{\circ} \mathrm{N}$ and $5^{\circ} \mathrm{S}$. The pattern of the total meridional transport hence reveals a seasonal variability of inter-hemispheric transport by crossequator Hadley cell circulations in the tropics around the year. The negative regions in Fig. 6 indicates the mean meridional transport of chemical species from low-concentration regions to high-concentration regions, while the positive regions indicate transport from high-concentration regions to low-concentration regions.

In the northern winter, the inter-hemispheric transport is dominated by the Northern Hemispheric Hadley circulation. This meridional circulation transports species from northern mid-latitude high chemical source regions to northern tropical relatively low concentration regions. The total effect of this meridional transport produces positive tendencies in Barbados. In the northern summer, the inter-hemispheric transport is dominated by the Southern Hemispheric Hadley circulation. This cross-equator meridional circulation transports species from Southern Hemispheric low concentration regions, across the equator, to northern tropical relatively high-concentration regions. The total effect of this cross-equator meridional transport produces negative tendencies in Barbados.

The different transport pattern between winter and summer is mainly caused by the seasonal variation of cross-equator Hadley circulations. This cross-equator circulation produces net seasonal southward or northward inter-hemispheric transport of chemical species. In the northern summer, Barbados is under the influence of the southern cross-equator hemispheric Hadley circulation, while in the northern winter, Barbados is under the influence of the northern cross-equator Hadley circulation.

The vertical transport by cloud convection in Fig. 7 shows a completely different pattern of vertical transport between Barbados and Samoa. In Barbados, the most vigorous vertical transport appears to be in the northern winter. The vertical dipole pattern with positive regions from $2 \mathrm{~km}$ to $10 \mathrm{~km}$ and negative regions below $2 \mathrm{~km}$, illustrate an active upward transport of chemical species from the lower troposphere into the free troposphere. In Samoa, the most vigorous vertical transport appears to be in the Southern Hemisphere winter. The vertical dipole pattern with positive regions below $2 \mathrm{~km}$ and negative regions from $2 \mathrm{~km}$ to $7 \mathrm{~km}$, illustrate an active downward transport of chemical species from the upper troposphere into the lower troposphere.

The very delicate phase relationship between the active vertical dipole transport pattern by cloud convection and positive transport pattern by total meridional transport in Barbados illustrates an effective combined transport process between large-scale advection and cloud convection. This kind of combined transport process provides an active mechanism for chemical species to maintain an efficient upward mass flux in the northern site, Barbados, and downward mass flux in the southern site, Samoa (Dickerson et al., 1987).

The overall pattern of transport by large-scale advection is summarized in Fig. 8 for each hemisphere. These hemispheric averaged results provide a clear distinction between Northern and Southern Hemispheres. Chemically, the Northern Hemisphere accounts for about $95 \%$ of the total $\mathrm{CH}_{3} \mathrm{CCl}_{3}$ and $\mathrm{CFCl}_{3}$ 

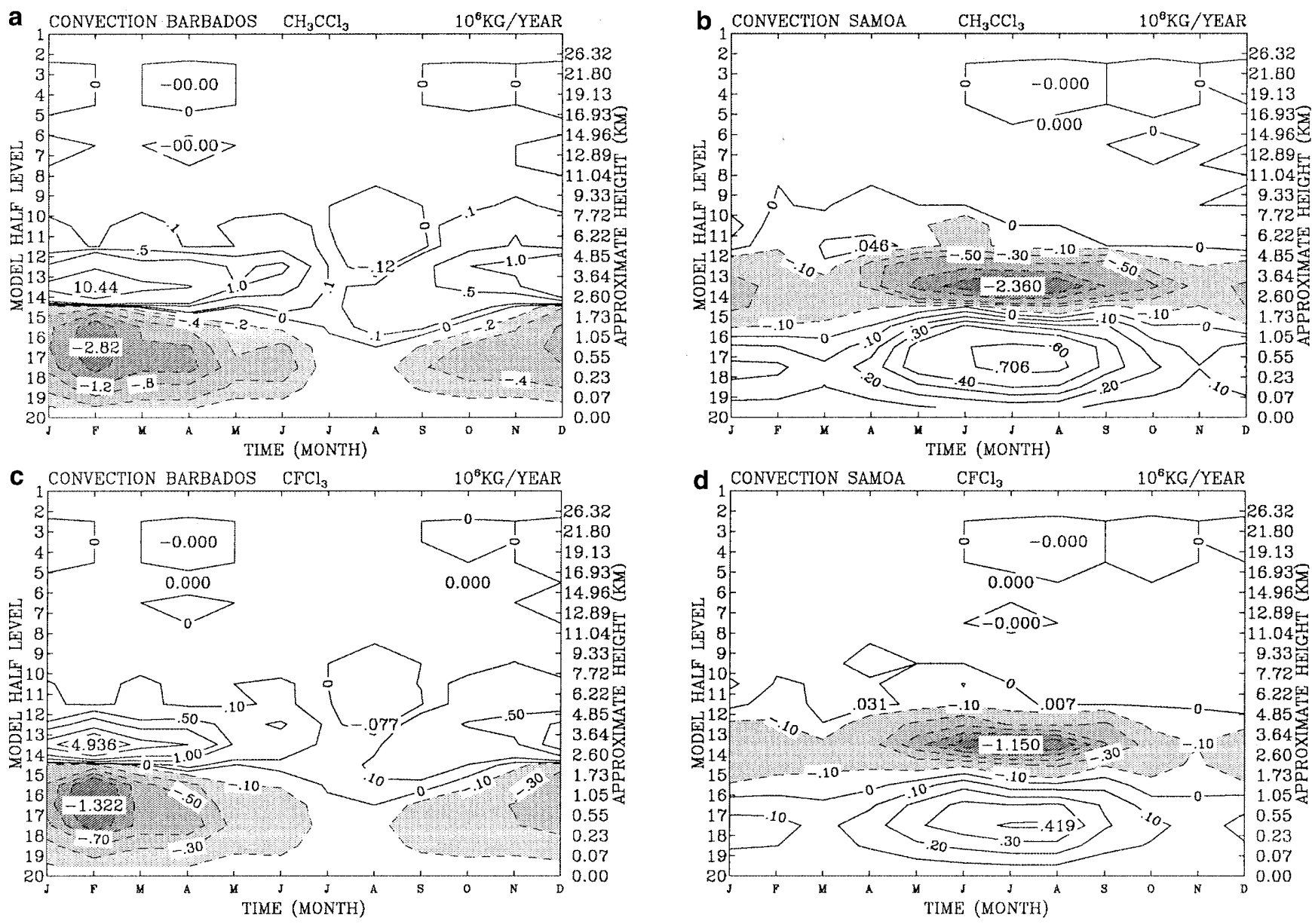

Fig. 7a-d. Height-time plots of $\mathbf{a}, \mathbf{b} \mathrm{CH}_{3} \mathrm{CCl}_{3}$ and $\mathbf{c}, \mathbf{d} \mathrm{CFCl}_{3}$ budget due to cloud convection at both Barbados (a, c) and Samoa (b, d) sites

emissions. Dynamically, the chemical species derived from the northern emissions are transported to the Southern Hemisphere by inter-hemispheric transport which results in an equivalent growth rate of observed chemical concentration compared with the north. The effect of inter-hemispheric transport is clearly seen in the Southern Hemisphere. The positive pattern illustrates the net transport of chemical species from higher concentration areas to lower concentration areas. This kind of down-gradient transport of species provides an essential mechanism for the maintenance of globally near homogeneous trends of observed surface concentration. The positive patterns seen in the Northern Hemispheric winter demonstrate the active season for the southward transport of high-concentration air from northern high latitudes. The negative patterns seen in the Northern Hemispheric summer demonstrate the active season for the northward transport of lowconcentration air from southern low latitudes. This cross-equator northern Hadley cell circulation may reflect the contributions of the monsoons of South Asia and Africa (Hastenrath, 1985).

Figure 9 summarizes the averaged effects of vertical transport by cloud convection in the Northern and Southern Hemisphere. We found this result is similar to the convective pattern of Fig. 6 . The cloud convection produces upward transport of chemical species in the Northern Hemisphere and downward transport of chemical species in the Southern Hemisphere. The upward transport of chemical species from the lower troposphere into the middle and upper troposphere could have a profound impact on the chemistry of $\mathrm{CH}_{3} \mathrm{CCl}_{3}$ and $\mathrm{CFCl}_{3}$. The wind speed is higher in the upper troposphere and hence the distance of long-range transport is longer than when both species are constrained in the lower troposphere. For $\mathrm{CH}_{3} \mathrm{CCl}_{3}$, the major chemical reaction is with tropospheric $\mathrm{OH}$ radicals. The vertical structure of tropospheric $\mathrm{OH}$ is influenced by the competing factors of mixing ratio of water vapour (which decreases rapidly with height), the number density of $\mathrm{O}_{3}$ (which has a maximum between 600 and $800 \mathrm{hPa}$ ), and the magnitude of photolysis rate constants $J$ and reaction rate constants $k$ (which are determined by the solar irradiance, temperature, and clouds). The resulting maximum rate of $\mathrm{OH}$ production is at around 800 mbar (Spivakovsky et al., 1990). Hence, the budget of $\mathrm{CH}_{3} \mathrm{CCl}_{3}$ in the troposphere could be very sensitive to the variation in vertical structure of $\mathrm{OH}$ modified by cloud convection (Thompson et al., 1994).

The chemical reaction for $\mathrm{CH}_{3} \mathrm{CCl}_{3}$ in the Northern and Southern Hemisphere (upper panel of Fig. 10) illustrate an active sink due to reaction with by $\mathrm{OH}$ 

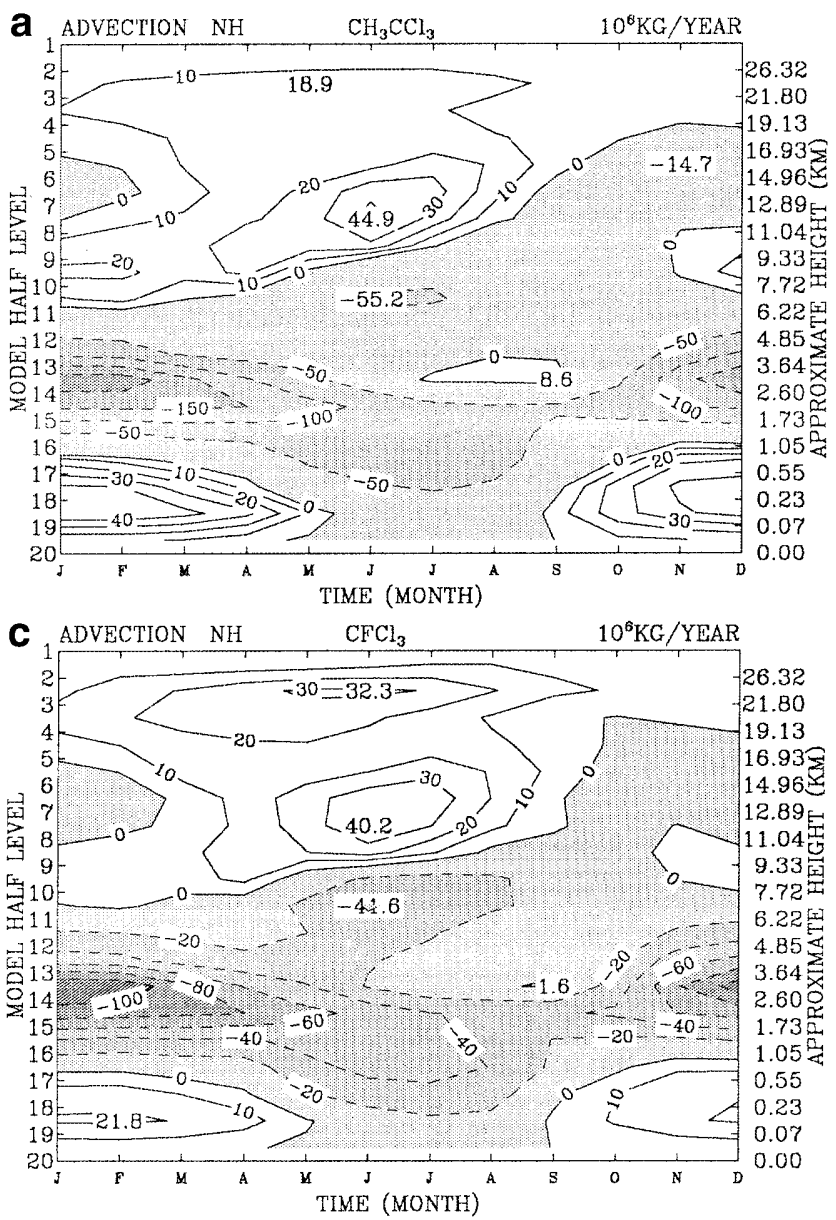
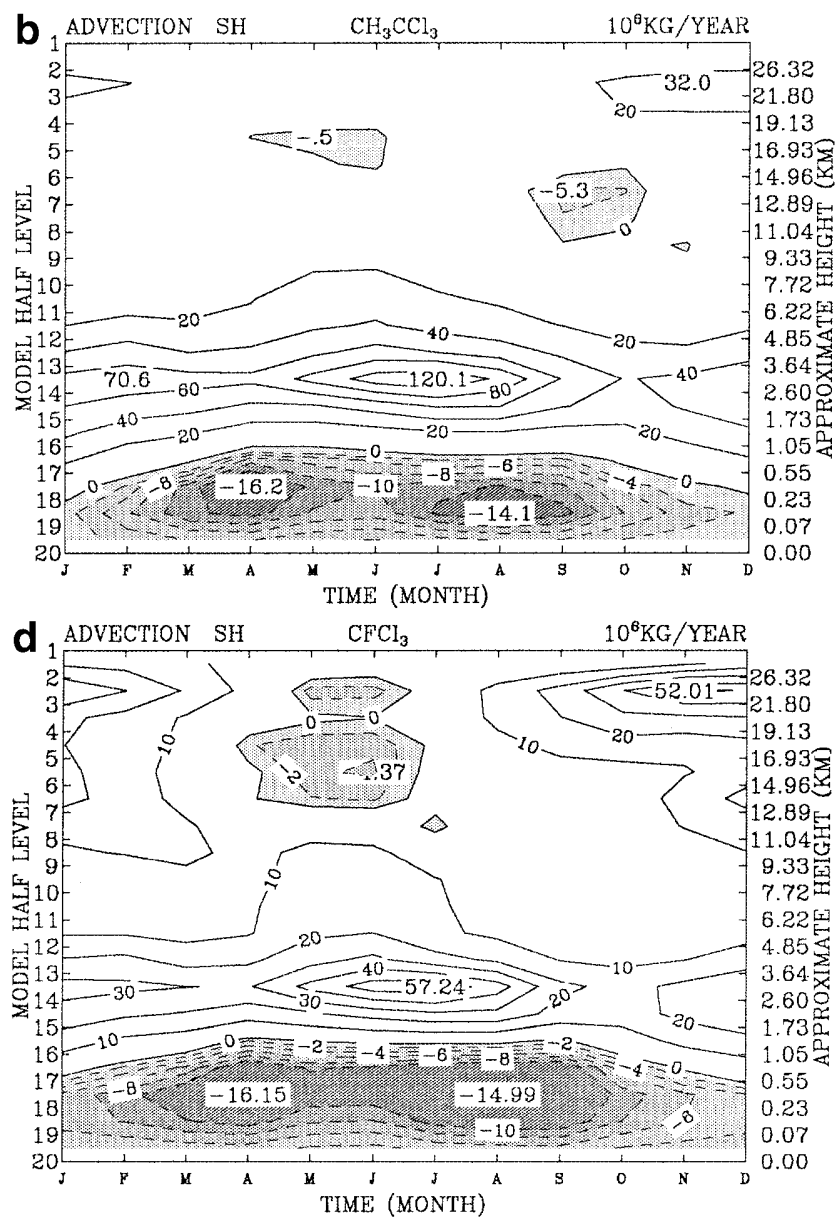

Fig. 8a-d. Horizontally averaged mean meridional transport of $\mathbf{a}, \mathbf{b} \mathrm{CH}_{3} \mathrm{CCl}_{3}$ and $\mathbf{c}, \mathbf{d ~ C F C l}$ due to large-scale transport for Northern $(\mathbf{a}, \mathbf{c})$ and Southern (b, d) Hemispheres

in the troposphere, and sink due to ultraviolet photolysis in the lower stratosphere. The amplitude of photolysis in the lower stratosphere is consistent with the season, which is a direct response to the seasonal variation of the intensity of incoming solar radiation. Such agreement between season and the strength of photolysis can also be seen from the chemical reaction for $\mathrm{CFCl}_{3}$ (lower panel of Fig. 10). The major sink for $\mathrm{CFCl}_{3}$ is exclusively stratospheric photolysis and reaction with $\mathrm{O}\left({ }^{1} \mathrm{D}\right)$.

The maximum rate of extinction for $\mathrm{CH}_{3} \mathrm{CCl}_{3}$ by the $\mathrm{OH}$ radical is $41 \mathrm{kT} \mathrm{yr}^{-1}$ in the northern summer, and $27 \mathrm{kT} \mathrm{yr}^{-1}$ in the southern summer (northern winter). The area for this chemical reaction is located at the altitude between $1 \mathrm{~km}$ and $6 \mathrm{~km}$, with maximum amplitude occurring at the height of $3.5 \mathrm{~km}$. The stratospheric photolysis sink is $17 \mathrm{kT} \mathrm{yr}^{-1}$ in the northern summer, and $18 \mathrm{kT} \mathrm{yr}^{-1}$ in the southern summer. The Northern Hemisphere has higher rates of extinction by reaction with $\mathrm{OH}$ than the Southern Hemisphere; while the Southern Hemisphere has slightly higher stratospheric sinks for $\mathrm{CH}_{3} \mathrm{CCl}_{3}$. This shows that the active northern summer removal of $\mathrm{CH}_{3} \mathrm{CCl}_{3}$ by $\mathrm{OH}$ helps to reduce the total amount of that species being transported into the lower stratosphere.
Figure 11 shows the mean meridional structure of vertically integrated chemical sinks for both species. Both species have maximum sinks between $60^{\circ} \mathrm{N}$ and $60^{\circ} \mathrm{S}$. The extinction rate in the southern summer $\left(24 \mathrm{kT} \mathrm{yr}^{-1}\right)$ is higher than in the northern summer $\left(19 \mathrm{kT} \mathrm{yr}^{-1}\right)$ for $\mathrm{CFCl}_{3}$. This is consistent with our previous argument of stronger solar insolation at the top of the Southern Hemisphere. The tropospheric sink of $\mathrm{CH}_{3} \mathrm{CCl}_{3}$ by $\mathrm{OH}$ is closely related to factors like temperature, UV irradiance, clouds, $\mathrm{H}_{2} \mathrm{O}, \mathrm{CO}, \mathrm{O}_{3}$, $\mathrm{CH}_{4}$, and $\mathrm{NO}_{t}$ (defined as $\mathrm{NO}+\mathrm{NO}_{2}+\mathrm{NO}_{3}+$ $2 \mathrm{~N}_{2} \mathrm{O}_{5}+\mathrm{HNO}_{2}+\mathrm{HNO}_{4}$ ) (Spivakovsky et al., 1990), and stratospheric $\mathrm{O}\left({ }^{1} \mathrm{D}\right)$ which is closely related to the stratospheric $\mathrm{O}_{3}$ concentration and solar insolation.

\section{Further considerations}

Based on the analysis shown in this study, we are able to make the following statements. First, the model emissions could be too high for both species. It would seem from Figs. 1 and 2 that the emissions used for the first few years of the model integration are reasonable. But that subsequently, the modelled levels have tended to be too high, resulting in the difference between model and 

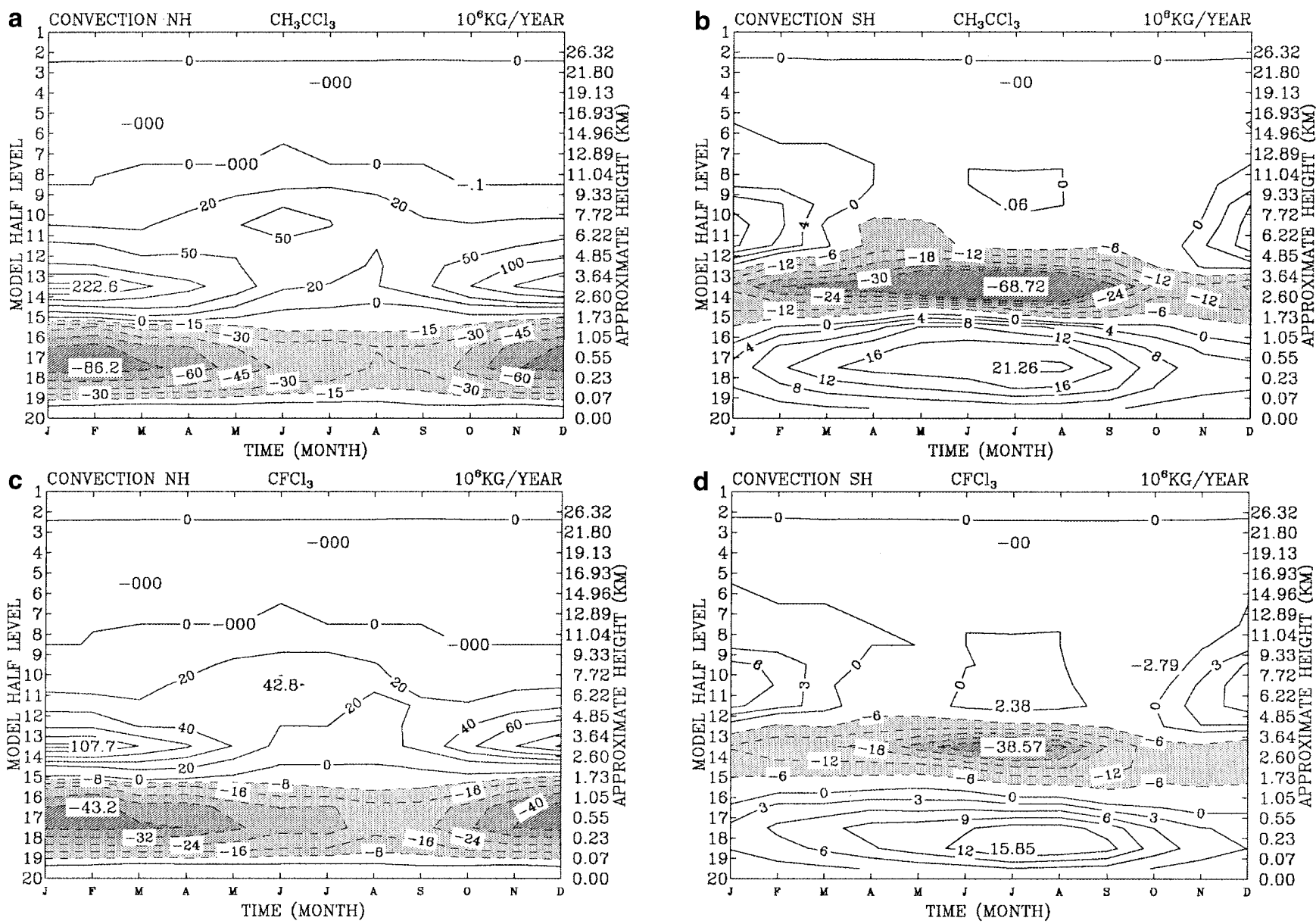

Fig. 9a-d. The same as in Fig. 8 but for cloud convective transport

measurement at the end of the 10 year integration. For $\mathrm{CFCl}_{3}$, its trend during a 10 -year integration is completely dominated by the surface emission strength. Hence the year-to-year emissions during the 1979-1988 period are very likely to be lower than used here. For $\mathrm{CH}_{3} \mathrm{CCl}_{3}$, its trends also indicates that modelled levels are too high compared with measurements. Hence, its emissions used here may also be too high.

Figure 12 shows a comparison of emissions used in this study with estimated emissions, and emissions used in Krol et al. (1998). The estimated emissions are calculated based on: (1) the observed trend of $90.34 \mathrm{pptv}$ for $\mathrm{CFCl}_{3}$ and 57.51 pptv for $\mathrm{CH}_{3} \mathrm{CCl}_{3}$ between 1979 and 1988 within the troposphere (defined as the region below $250 \mathrm{hPa}$ ); and (2) the estimated lifetime of $\mathrm{CFCl}_{3}$ (43-50 years) and $\mathrm{CH}_{3} \mathrm{CCl}_{3}$ (4.1-5.4 years). For $\mathrm{CFCl}_{3}$, it is clear that the model employed emissions which were about $26 \%-32 \%$ higher than estimated emissions (corresponding to 35-41 pptv increase in $\mathrm{CFCl}_{3}$ ); while for $\mathrm{CH}_{3} \mathrm{CCl}_{3}$, the model employed emissions which were about $4 \%-19 \%$ higher (corresponding to $13-52 \mathrm{pptv}$ increase in $\mathrm{CH}_{3} \mathrm{CCl}_{3}$ ). The modelled averaged concentrations at the end of the 10-year integration are about 23 pptv and 35 pptv higher than observed levels for $\mathrm{CFCl}_{3}$ and $\mathrm{CH}_{3} \mathrm{CCl}_{3}$, respectively. It is clear that the emissions used here could be too high, however, other factors should be considered.

Second, the externally prescribed 2-D OH, photolysis rates, and $\mathrm{O}\left({ }^{1} \mathrm{D}\right)$ fields may be one of the uncertainties for long-term model integrations for species which are strongly influenced by the temporal and spatial variations of $\mathrm{OH}$. It is somewhat unrealistic for $\mathrm{OH}$ concentrations to be constant for 10 years (see also Krol et al., 1998). In addition, though the model shows pronounced seasonal variations of $\mathrm{CH}_{3} \mathrm{CCl}_{3}$ at Oregon and Barbados as compared with the measurements, no pronounced seasonal $\mathrm{CH}_{3} \mathrm{CCl}_{3}$ variations are seen at Tasmania. It may be that the 2-D OH field is poorly prescribed in the Southern Hemisphere, or that there are sources in the Southern Hemisphere which are not included here.

Third, there may be inadequate model representation of air mass exchange between the lower stratosphere and the upper troposphere. Considering the major sinks of $\mathrm{CFCl}_{3}$ calculations show that the loss of $\mathrm{CFCl}_{3}$ can only occur first by the photolysis of $\mathrm{CFCl}_{3}$; and second by the gas phase reaction between $\mathrm{CFCl}_{3}$ and $\mathrm{O}\left({ }^{1} \mathrm{D}\right)$. Let us note two facts: first, the trend of observed surface concentration is nearly the same from north to south; second, almost all of the sources are coming from the north. Hence the observed trend of surface concentration in the Southern Hemisphere is clearly coming from the Northern Hemisphere. The processed air reaching the Southern Hemisphere must clearly experience 

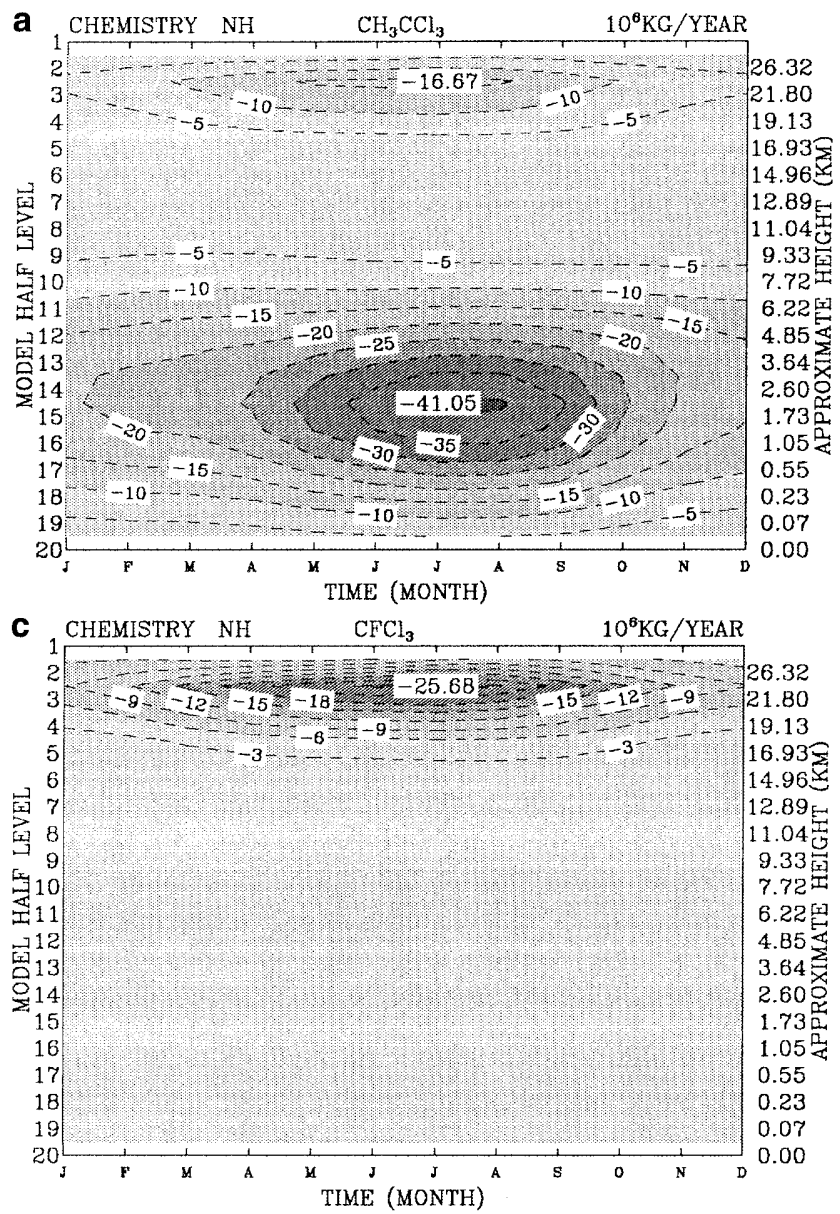
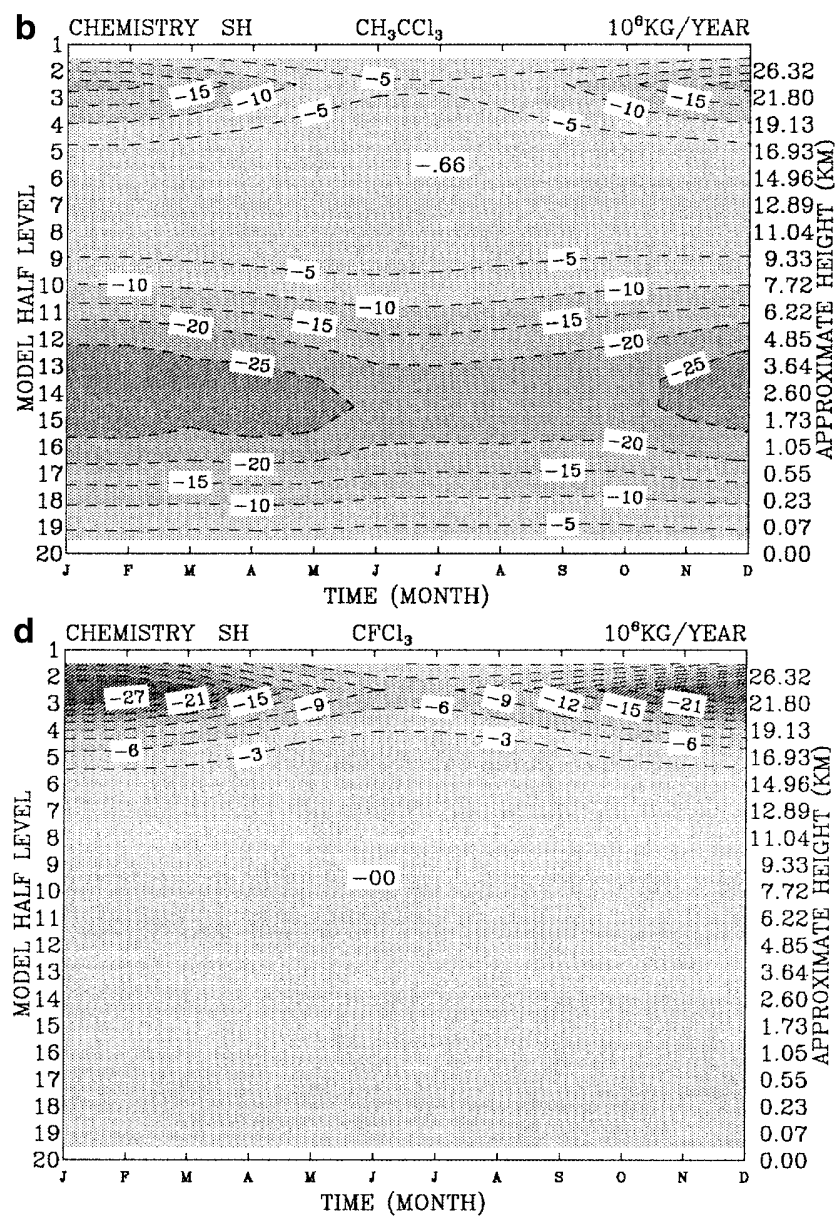

Fig. 10a-d. Height-time plots of horizontally integrated chemical sinks due to chemical reactions between tropospheric $\mathrm{CH}_{3} \mathrm{CCl}_{3}$ and $\mathrm{OH}$, and stratospheric photolysis of $\mathbf{a}, \mathbf{b} \mathrm{CH}_{3} \mathrm{CCl}_{3}$ and $\mathbf{c}, \mathbf{d}$ stratospheric chemical reactions between $\mathrm{CFCl}_{3}$ and $\mathrm{O}\left({ }^{1} \mathrm{D}\right)$, and photolysis of $\mathrm{CFCl} 3$
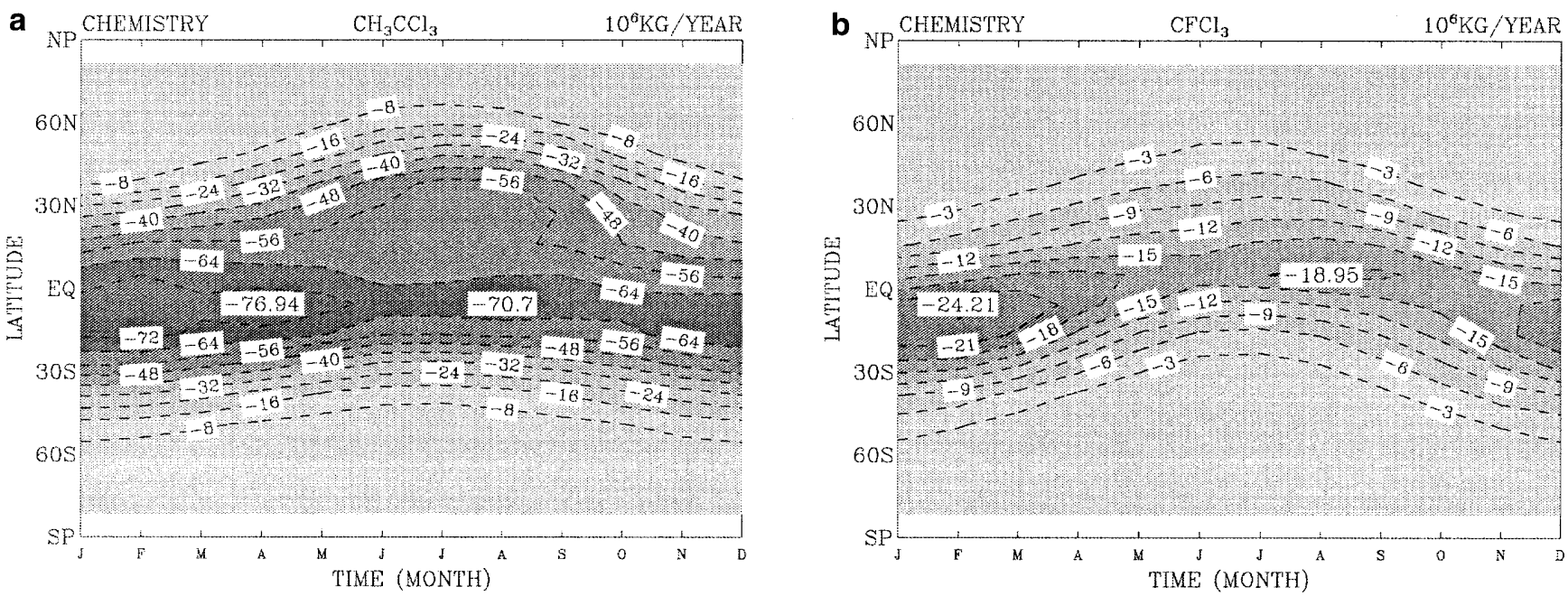

Fig. 11a, b. Latitude-time plots of vertically integrated chemical sinks of a $\mathrm{CH}_{3} \mathrm{CCl}_{3}$ and $\mathbf{b} \mathrm{CFCl}_{3}$

photolysis and gas phase chemical reactions in the lower stratosphere. Therefore the strength of the transport between troposphere and lower stratosphere and the amount of the air taking part in the chemical reactions in the lower stratosphere will directly influence the amount of air to be processed by $\mathrm{O}\left({ }^{1} \mathrm{D}\right)$ and photolysis in the stratosphere. Since the magnitude of the increase in modelled averaged concentrations at the end of the 10 -year integration (23 pptv) is lower than the magnitude of the increase due to higher emissions used in the model (35-41 pptv), the model chemical sinks in the lower stratosphere are likely to be faster than in reality. 

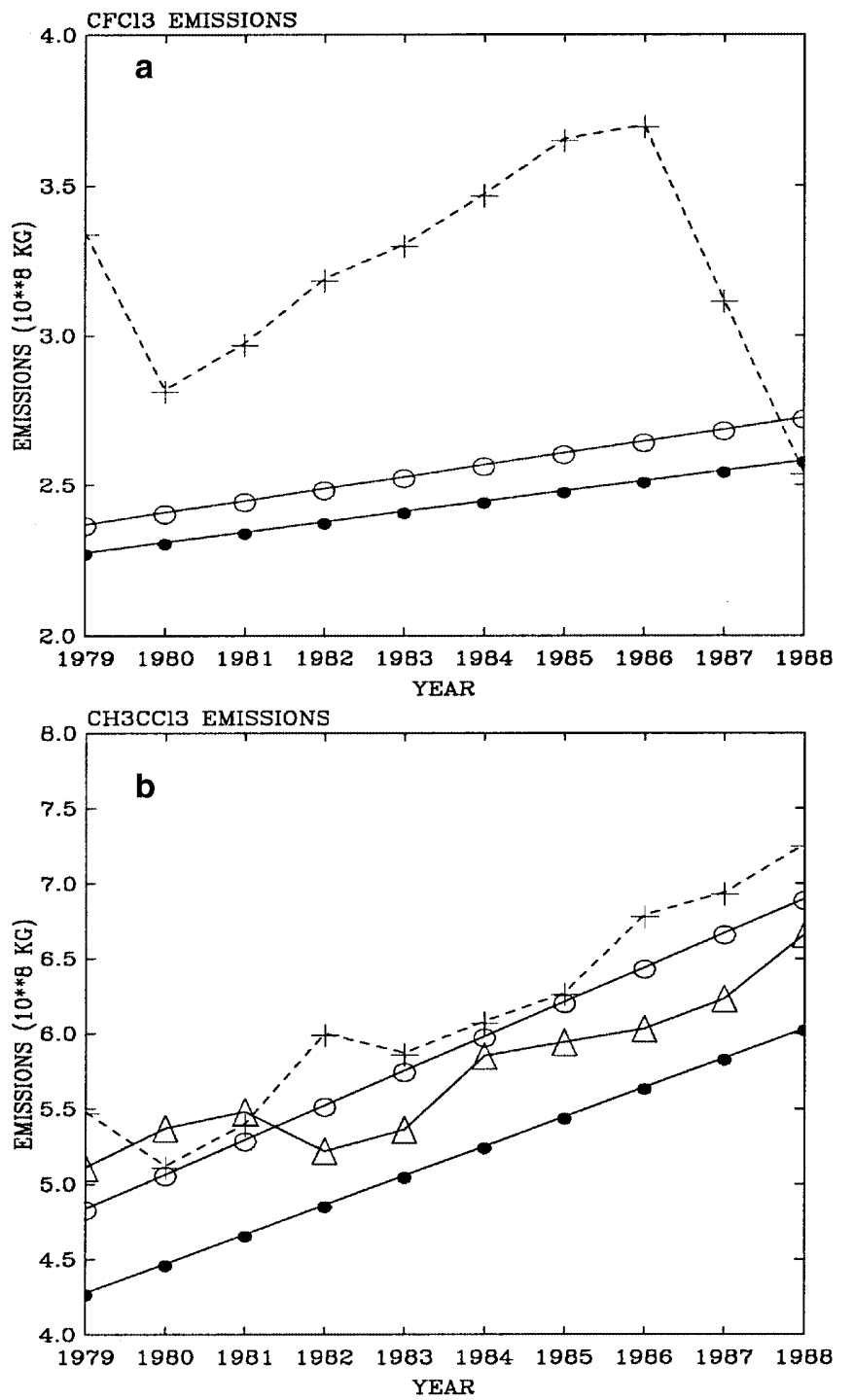

Fig. 12a, b. Time series plots of the emissions used in this study for a $\mathrm{CFCl}_{3}$ and $\mathbf{b} \mathrm{CH}_{3} \mathrm{CCl}_{3}$. The emissions used here are denoted by plus signs $(+)$. Also shown in the plots are the estimated emissions. For $\mathrm{CFCl}_{3}$, the open circles correspond to a lifetime of 43 years, while the solid circles correspond to a lifetime of 50 years. For $\mathrm{CH}_{3} \mathrm{CCl}_{3}$, the open and solid circles represent corresponding lifetime of 4.6 and 5.4 years, respectively. Emissions used in Krol et al. (1998) are shown in b and are denoted by open triangles, which have an averaged lifetime of 4.6 years

Finally, there are possible oceanic sinks for both species. There is already evidence of both $\mathrm{CH}_{3} \mathrm{CCl}_{3}$ (Tie et al., 1992) and $\mathrm{CFCl}_{3}$ in the seawater (e.g. Krol et al., 1998). There are no oceanic sinks for either species considered here. Notice that while the amounts of $\mathrm{CFCl}_{3}$ are traceable in the ocean, the amount dissolved in the ocean is likely too small to be a significant sink for atmospheric $\mathrm{CFCl}_{3}$.

\section{Summary}

The global ALE/GAGE network monitoring stations provide a continuous long-term record on the atmospheric concentration of anthropogenic chemical spe- cies. The observational results show some very important properties of man-made chemical species once they have been released into the atmosphere. The most interesting findings from the observations are the globally homogeneous trend (growth rate) and variability (spatial and temporal) of chemical species.

The observations reveal a generally growing surface concentration in the northern winter; while in the northern summer the surface concentration generally decays. Given that the rate of emission is the same within each year, only chemical reactions and dynamical transport could produce northern winter higher atmospheric burdens of $\mathrm{CH}_{3} \mathrm{CCl}_{3}$ and $\mathrm{CFCl}_{3}$ than in the northern summer.

The dynamics of the change (trend and variability) of the chemical concentration is closely correlated to the following factors. Chemically, the variation of concentration is driven by the chemical reaction which is a function of variational concentration of $\mathrm{OH}, \mathrm{O}\left({ }^{1} \mathrm{D}\right)$, and photolysis which is a function of variational intensity of solar insolation at the top of the atmosphere. During the northern winter, the chemical reactions between $\mathrm{CH}_{3} \mathrm{CCl}_{3}$ and $\mathrm{OH}$ are slower due to the lower tropospheric $\mathrm{OH}$ concentrations, and the reaction between $\mathrm{CFCl}_{3}$ and $\mathrm{O}\left({ }^{1} \mathrm{D}\right)$ is slower due to the lower stratospheric $\mathrm{O}\left({ }^{1} \mathrm{D}\right)$ concentrations, and finally the lower stratospheric photolysis rate for both species is slower due to the smaller solar insolation at the top of the atmosphere in the winter. Dynamically, the variation of hemispheric concentration is governed by the variational inter-hemispheric transport which is dominated by the cross-equator Hadley cell circulations. They regulate the strength of inter-hemispheric transport in different seasons.

Acknowledgements. We thank Mike Blackburn of Reading University for support with the UGCM AMIP data; Carbon Dioxide Information Analysis Center, Oak Ridge National Laboratory, USA, for the ALE/GAGE data; Martyn Chipperfield on the TOMCAT model; Martin Heimann and Zoë Stockwell on the Tiedtke and Lois scheme; and J.A. Pyle and D.J. Lary for their support of the research. We would also like to thank two anonymous reviewers for their insightful comments that greatly improved the clarity of this work. The Centre for Atmospheric Science is a joint initiative of the Department of Chemistry and the Department of Applied Mathematics and Theoretical Physics. This work forms part of the NERC UK Universities Global Atmospheric Modelling Programme.

Topical Editor D. Murtagh thanks two referees for their help in evaluating this paper.

\section{References}

Cunnold, D., P. Fraser, R. Weiss, R. Prinn, P. Simmonds, B. Miller, F. Alyea, and A. Crawford, Global trends and annual releases of $\mathrm{CCl} 3 \mathrm{~F}$ and $\mathrm{CCl} 2 \mathrm{~F} 2$ estimated from ALE/GAGE and other measurements from July 1978 to June 1991, J. Geophys. Res., 99(D1), 1107-1126, 1994.

Deardorff, J. W., Parametrization of the planetary boundary layer for use in general circulation models, Mon. Weather Rev., 97, 835-844, 1972.

DeMore, W. B., Relative rate constants for the reactions of $\mathrm{OH}$ with methane and methyl chloroform, Geophys. Res. Lett., 19, 1367-1370, 1992. 
Denning, A. S., M. Holzer, K. R. Gurney, M. Heimann, R. M. Law, P. L. Rayner, I. Y. Fung, S. M. Fan, S. Taguchi, P. Friedlingstein, Y. Balkanski, J. Taylor, M. Maiss, and I. Levin, Threedimensional transport and concentration of SF6 - a model intercomparison study (TransCom 2), Tellus Ser. B, 51, 266297, 1999.

Dickerson, R. R., G. J. Huffman, W. T. Luke, L. J. Nunnermacker, K. E. Pickering, A. C. D. Leslie, C. G. Lindsey, W. G. N. Slinn, T. J. Kelly, P. H. Daum, A. C. Delany, J. P. Greenberg, P. R. Zimmerman, J. F. Boatman, J. D. Ray, and D. H. Stedman, Thunderstorms: an important mechanism in the transport of air pollutants, Science, 235, 460-465, 1987.

Driedonks, A. G. M., Models and observations of the growth of the atmospheric boundary layer, Boundary-Layer Meteorol., 23, 283-306, 1982.

Gates, W. L., AMIP: the atmospheric model intercomparison project. PCMDI Report 7, 17pp., 1992.

Gilliland, A. B., and D. E. Hartley, Interhemispheric transport and the role of convective parameterizations, J. Geophys. Res., 103, 22 039-22 045, 1998.

Golombek, A., and R. G. Prinn, A global three-dimensional model of the circulation and chemistry of $\mathrm{CFCl}_{3}, \mathrm{CF}_{2} \mathrm{Cl}_{2}, \mathrm{CH}_{3} \mathrm{CCl}_{3}$, $\mathrm{CCl}_{4}$, and $\mathrm{N}_{2} \mathrm{O}$, J. Geophys. Res., 91(D3), 3985-4001, 1986.

Hartley, D., and R. G. Prinn, Feasibility of determining surface emissions of trace gases using an inverse method in a threedimensional chemical transport model, J. Geophys. Res., 98(D3), 5183-5198, 1993.

Hastenrath, S., Climate and circulation of the tropics, Reidel, Dordrecht, 1985.

Heimann, M., The global atmospheric tracer model TM2: model description and user manual, Model Version 8.5, Manual Version 0.95, 1994.

Holtslag, A. A. M., and B. A. Boville, Local versus nonlocal boundary layer diffusion in a global climate model, J. Clim. 6, 1825-1842, 1993.

Holton, J. R., An introduction to dynamic meteorology, Academic Press, New York., 1992

Hoskins, B. J., M. E. McIntyre, and A. W. Robertson, On the use and significance of isentropic potential vorticity maps, $Q$. J. R. Meteorol. Soc., 111, 877-946, 1985.

Houweling, S., T. Kaminski, F. Dentener, J. Lelieveld, and M. Heimann, Inverse modeling of methane sources and sinks using the adjoint of a global transport model, J. Geophys. Res., 104(D21), 26 137-16 160, 1999.

Kaye, J. A., S. A. Penkett, and F. M. Ormond, Report on concentrations, lifetimes, and trends of CFCs, halons, and related species, NASA Reference Publication 1339, January 1994.

Krol, M., P. J. van Leeuwen, and J. Lelieveld, Global OH trend inferred from methylchloroform measurements, J. Geophys. Res., 103, 10 697-10 711, 1998.

Law, K. S., and J. A. Pyle, Modeling trace gas budgets in the troposphere 1. Ozone and odd nitrogen, J. Geophys. Res., 98(D10), 18 377-18 400, 1993.

Louis, J. F., A parametric model of vertical eddy fluxes in the atmosphere, Bound.-Layer Meteorol., 17, 187-202, 1979.

Midgley, P. M., The production and release to the atmosphere of halocarbons, Ber. Bunsenges. Phys. Chem., 96, 293-296, 1992.

Müller, J.-F., and G. Brasseur, IMAGES: a three-dimensional chemical transport model of the global troposphere, J. Geophys. Res., 100(D8), 16 445-16 490, 1995.
Palmen, E., and C. W. Newton, Atmospheric circulation systems, Academic Press, New York, 1969.

Prather, M., M. McElroy, S. Wofsy, G. Russell, and D. Rind, Chemistry of the global troposphere: fluorocarbons as tracer of air motion, J. Geophys. Res., 92(D6), 6579-6613, 1987.

Prinn, R. G., P. G. Simmonds, R. A. Rasmussen, R. D. Rosen, F. N. Alyea, C. A. Cardelino, A. J. Crawford, D. M. Cunnold, P. J. Fraser, and J. E. Lovelock, The atmospheric lifetime experiment 1. Introduction, instrumentation, and overview, J. Geophys. Res., 88(C13), 8353-8367, 1983.

Prinn, R., D. Cunnold, P. Simmonds, F. Alyea, R. Boldi, A. Crawford, P. Fraser, D. Gutzler, D. Hartley, R. Rosen, and R. Rasmussen, Global average concentration and trend for hydroxyl radicals deduced from ALE/GAGE trichloroethane (methyl chloroform) data for 1978-1990, J. Geophys. Res., 97, 2445-2461, 1992.

Quay, P., J. Stutsman, D. Wilbur, A. Snover, E. Dlugokencky, and T. Brown, The isotopic composition of atmospheric methane, Glob. Biogeochem. Cyc., 13, 445-461, 1999.

Rhoads, K. P., P. Kelley, R. R. Dickerson, T. P. Carsey, M. Farmer, D. L. Savoie, and J. M. Prospero, Composition of the troposphere over the Indian Ocean during the monsoonal transition, J. Geophys. Res., 102(D15), 18 981-18 995, 1997.

Slingo, J. M., M. Blackburn, A. K. Betts, R. Brugge, K. D. Hodges, B. J. Hoskins, M. J. Miller, L. Steenman-Clark, and J. Thuburn, Mean climate and transience in the tropics of the UGAMP GCM: sensitivity to convective parametrization, $Q . J . R$. Meteorol. Soc., 120, 881-922, 1994.

Solomon, S., Stratospheric ozone depletion: a review of concepts and history, Rev. Geophys., 37, 275-316, 1999.

Spivakovsky, C. M., R. Yevich, J. A. Logan, S. C. Wofsy, and M. B. McElroy, Tropospheric $\mathrm{OH}$ in a three-dimensional dhemical tracer model: an assessment based on observations of $\mathrm{CH}_{3} \mathrm{CCl}_{3}$, J. Geophys. Res., 95(D11), 18 441-18 471, 1990.

Stockwell, D. Z., and M. P. Chipperfield, The TOMCAT offline transport model. Part III. Convection and vertical diffusion, UGAMP Internal Report, 44c, 20pp., 1996.

Stockwell, D. Z., and M. P. Chipperfield, A tropospheric chemicaltransport model: development and validation of the model transport schemes, Q. J. R. Meteorol. Soc., 125, 1747-1783, 1999.

Tie, X., C.-Y. Kao, E. J. Mroz, R. J. Cicerone, F. N. Alyea, and D. M. Cunnold, Three-dimensional simulations of atmospheric methyl chloroform: effect of an ocean sink, J. Geophys. Res., 97(D18), 20 751-20 769, 1992.

Tiedtke, M., A comprehensive mass flux scheme for cumulus parameterization in large scale models, Mon. Weather. Rev., 117, 1779-1800, 1989.

Thompson, A. M., K. E. Pickering, R. R. Dickerson, W. G. Ellis Jr, D. J. Jcob, J. R. Scala, W.-K. Tao, D. P. McNamara, and J. Simpson, Convective transport over the central United States and its role in regional $\mathrm{CO}$ and ozone budgets, J. Geophys. Res., 99, $18703-18711,1994$.

Vay, S. A., B. E. Anderson, T. J. Conway, G. W. Sachse, J. E. Collins, D. R. Blake, and D. J. Westberg, Airborne observations of the tropospheric $\mathrm{CO}_{2}$ distribution and its controlling factors over the South Pacific Basin, J. Geophys. Res., 104(D5), 56635676, 1999.

Wayne, R. P., Chemistry of atmosphere, Oxford University Press, Oxford, 1993. 